\title{
Constructing Coincident Indices of Economic Activity for the Latin American Economy*
}

\author{
João Victor Issler ${ }^{\dagger}$, Hilton H. Notini ${ }^{\ddagger}$, Claudia F. Rodrigues ${ }^{\S}$, Ana \\ Flávia Soares
}

\author{
Contents: 1. Introduction; 2. Literature Review; 3. Theoretical underpinnings; 4. Empirical \\ Results; 5. The Coincident Indicator; 6. Conclusion; A. Appedinx Tables. \\ Keywords: Latin America; Coincident Indicators; Business Cycles; Kalman Filter; State-Space \\ Models. \\ JEL Code: C32, E32
}

This paper has three main contributions. The first is to propose an individual coincident indicator for the following Latin American countries: Argentina, Brazil, Chile, Colombia and Mexico. In order to obtain similar series to those traditionally used in business-cycle research in constructing coincident indices (output, sales, income and employment) we were forced to back-cast several individual country series which were not available in a long time-series span. The second contribution is to establish a chronology of recessions for these countries, covering the period from 1980 to 2012 on a monthly basis. Based on this chronology, the countries are compared in several respects. The final contribution is to propose an aggregate coincident indicator for the Latin American economy, which weights individual-country composite indices. Finally, this indicator is compared with the coincident indicator (The Conference Board - TCB) of the U.S. economy. We find that the U.S. indicator Granger-causes the Latin American indicator in statistical tests

Esse artigo tem 3 contribuições à literatura de ciclos de negócios. A primeira é a de construir indicadores coincidentes de atividade econômica

\footnotetext{
* We gratefully acknowledge the comments made by the Editor (Cézar Santos) and one anonymous referee. We also acknowledge the excellent research assistance of Beatriz Urbano, Marcia Waleria Machado, Marcia Marcos and Rafael Burjack. João Victor Issler thanks the financial support given by CNPq, FAPERJ, and INCT. All remaining errors are ours.

${ }^{\dagger}$ FGV/EPGE E-mail: jissler@fgv.br

${ }^{\ddagger}$ Itaú Unibanco Holding S.A. E-mail: hiltinhonotini@yahoo.com. br

$\S$ VALE, Investor Relations E-mail: claudia_fontoura@yahoo.com

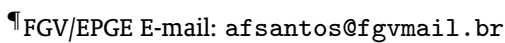


para Argentina, Brasil, Chile, Colômbia e México, usando pesos idênticos para as séries de Emprego, Produção, Renda, e Vendas. Para tal, tivemos que fazer o back-cast de algumas séries chave para poder construir esses indicadores. A segunda é a de estabelecer uma cronologia de recessões para esses países no período 1980-2012 em bases mensais. Com base na última, fazemos comparações em várias dimensões. Finalmente, nossa última contribuição é propor um índice coincidente agregado para a América Latina, que é comparado ao índice agregado dos EUA. Esta comparação indica que o índice coincidente dos EUA Granger-causa o da América Latina, mas a recíproca não é verdadeira

\section{INTRODUCTION}

An important concern of any modern society is to determine the current state of the economy and what should it be in the near future. The lack of a direct measure for the state of the economy has led to the construction of proxies that can be used in real time. These are the so-called coincident indices of economic activity, see Burns and Mitchell (1946), Stock and Watson (1988a,b, 1989, 1991, 1993b), Mariano and Murasawa (2003), Chauvet (1998), Harding and Pagan (2002), Issler and Vahid (2006), and Chauvet and Piger. (2008).

A major difficulty in this line of research for Latin America is the scarcity of reliable databases with a long time-series span in high frequency (monthly data). Indeed, most business-cycle studies in Latin America relied on annual data, and the ones with quarterly data are the exception; see, for example, Engle and Issler (1993), Calvo et al. (1992), Hecq et al. (2006), and, more recently, Aiolfi et al. (2011). Since business-cycle research worldwide is conducted using monthly data, the scarcity of reliable highfrequency databases in Latin America has been a key obstacle for business-cycle studies in the region as a whole and in individual countries.

This paper has three main contributions. The first is to propose a coincident indicator for the following Latin American countries: Argentina, Brazil, Chile, Colombia and Mexico, whose GDP amount to more than $70 \%$ of GDP of the region as a whole. Based on previous research (Duarte et al. (2004), Issler and Vahid (2006), and Issler et al. (2012)) we chose to compute coincident indices using the techniques put forth by The Conference Board (TCB). In order to obtain similar series to those defined by TCB in constructing coincident indices (output, sales, income and employment) we chose to back-cast various individual country series; see the discussion in Issler, Notini and Rodrigues, who proposed a state-space procedure based on the interpolation method of Bernanke et al. (1997) and Mönch and Uhlig (2005). The back-casting method employed here is highly flexible and nests a wide range of dynamic models in the state-space form to back-cast the series of interest. As usual, the estimation of the unobserved components in these models employs the Kalman filter.

The second contribution of the paper is to establish a chronology of recessions for these countries, covering the period from 1980 to 2012 on a monthly basis. The dating of recessions is a valuable tool in understanding the sources of business-cycle fluctuations since it allows cross-country comparisons with other countries for which the understanding of business-cycle fluctuations is more advanced. Our final contribution is to propose an aggregate coincident index for the Latin American economy, weighting the individual composite indicators for countries, and comparing the resulting coincident indicator with its U.S. counterpart.

The empirical results allow investigating how synchronized regional economies in Latin America are in terms of business-cycle phases. They also allow comparisons with composite indices from other regions, such as the U.S. or Europe. The composite regional index for Latin America proposed here tracks reasonably well its economic activity, although not all countries follow it closely. Indeed, for the 
sample of countries studied here, on average, recessions are more frequent than in the U.S., the only exception being Chile. Regarding the magnitude of the 2007/2008 global financial crisis, all countries were affected in a similar way. Finally, a chronology of recessions in the region was established and compared with the chronology of the U.S. business cycle, supporting the idea that the U.S. cycle Grangercauses the Latin-American cycle, but it is not caused by it.

This article is organized as follows: Section 2 contains a brief review of the international and the Latin American literature. Section 3 presents the Kalman filter model. Section 4 presents the data and the main back-casting results. Section 5 presents the coincident indices for the observed Latin American countries and their respective turning points. Section 6 concludes.

\section{LITERATURE REVIEW}

\subsection{International Experience}

There has been a fair amount of research on cyclical indicators since the pioneering work of Arthur F. Burns and Wesley Mitchell. Although their research on the subject was focused on the U.S. economy, the method could be applied in a "global scale". Indeed, European research based on their methods started after World War II while the same happened in Latin America on the second half of the 1990s.

The National Bureau of Economic Research (NBER) is a research organization founded in 1920, dedicated to promoting a better understanding of how the global economy works. The NBER Business Cycle Dating Committee maintains a chronology of the U.S. business cycle and identifies the dates of peaks and troughs that shape economic recessions or expansions.

The time it takes for the NBER committee to deliberate and decide that a turning point has occurred is often too long to make these announcements practically useful. This gives importance to two constructed indices, namely the coincident index and the leading indicator index. The traditional coincident index constructed by the Department of Commerce is a combination of four representative monthly variables on total output, income, employment and trade. These variables are believed to have cycles that are concurrent with the latent "business cycle".

TCB approach is somewhat heuristic since it requires no estimation of a formal econometric model. Despite that, it works surprisingly well in practice. Issler and Vahid (2006) compared the dating abilities of TCB's index with that of alternative econometric-based indices: the state of the economy dated by TCB's index is much closer to the states dated by NBER than the ones dated by the techniques put forth by Stock and Watson $(1989,1993 \mathrm{~b})$ using a factor model and the techniques proposed by Issler and Vahid themselves, based on a fitted structural model for NBER's decisions. As an alternative to heuristic methods, such as TCB's, several authors have proposed methods of building indices supported by sophisticated econometric and statistical techniques. Stock and Watson were the first to apply the tools of modern time-series econometrics to build an approach able to construct leading and coincident indices, to detect turning points of economic activity, and to predict the probability of a recession. Their models formalize the idea that the reference cycle is best measured by looking at co-movements across several aggregate time series and making their experimental index an estimate of the value of a single unobserved variable - the "state of the economy". The observable variables used in estimating the state of the economy are the usual coincident series: industrial production, income, sales and employment, which are forecasted employing additional leading series.

An important empirical drawback in Stock and Watson's approach was its failure to detect the U.S. recession in 1990-1991. Many papers tried to improve on Stock and Watson's method while keeping the formal building block of a structural econometric model. We review here just a few of them.

Chauvet (1998) improved on Stock and Watson's model with the inclusion of regime switching as proposed by Hamilton (1989). The idea is to capture asymmetries between expansions and contractions of the economic activity. It relies in the fact that contractions are more abrupt and shorter than expansions. 
Forni et al. (2000) proposed an alternative approach to Stock and Watson's which is very close to the latter in spirit. In its more recent versions, these authors build a dynamic common-factor model instead of a static one, i.e., based on current and lagged coincident series, not just current coincident series.

Mariano and Murasawa (2003) extended Stock and Watson model in order to allow the use of mixedfrequency series, where GDP (quarterly measured) plays a key role. The coincident index is now the common factor of all four coincident series and also to interpolated monthly GDP, a sub-product of the analysis.

Finally, Issler and Vahid proposed fitting a structural instrumental-variable PROBIT model to detect NBER's state of the economy, where common cycles are imposed among the coincident series and past observations for the coincident and leading series are used as instruments.

\subsection{Latin America Experience}

Latin America is notoriously absent in the well-known historical business cycle studies by Sheffrin (1988) and Backus and Kehoe (1992), and only Brazil is covered in more recent work along similar lines. Instead, recent research on Latin American business cycles has been either country-specific, covering only short periods of time, or focused on specific transmission mechanisms (Hoffmaister and Roldos, 1997; Kydland and Zarazaga (1997); Neumeyer and Perri (2005).

A major difficulty in this line of research for Latin America is the scarcity of reliable databases with a long time-series span. Therefore, research on business cycles in the region was not as developed as in other regions or countries of the world.

Calvo et al. (1992) established that U.S. recessions and low international interest rates are key factors in explaining capital flows to Latin America, which ultimately generate output booms.

Engle and Issler (1993) used the Beveridge-Nelson trend-cycle decomposition to test for the existence of common trends and common cycles in the real GDPs of Argentina, Brazil, and Mexico during 1948-86. Unlike the present paper, they do not establish the dating of business cycles in these countries or for the region as a whole. Despite that, they found that the inverted Latin American business cycle closely follows the U.S. business cycle.

Aiolfi et al. (2011) develop a dynamic common factor approach to reconstruct new business cycle indices for Argentina, Brazil, Chile, and Mexico from an unprecedentedly comprehensive dataset on sectorial output, trade, fiscal and financial variables spanning 135 years.

In the case of Brazilian economy, with the exception to the work of Contador (1977) and Contador and Ferraz (1999), research on coincident and leading indices is fairly young and most of the literature dates from the 2000's. Chauvet (2001) and Picchetti and Toledo (2002) use common-factor models to generate a monthly coincident indicator of economic activity. Chauvet (2002) uses a two-state Markov Chain characterizing a recession or an expansion to propose a chronology for Brazilian business cycles.

On a broader study on Brazil, Issler et al. (2012) followed Duarte et al. and applied TCB's methodology to construct a coincident index of economic activity. They devote a lot of effort in reconstructing coincident series using a novel State-Space representation. Once they obtain a long enough span of the usual series used in TCB's method, they compute a new composite coincident index of Brazilian economic activity, whose dating of recessions is close to those in Duarte et al. and to those implied by the monthly GDP estimate proposed by Issler and Notini (2008). 


\section{THEORETICAL UNDERPINNINGS}

\subsection{The Methodology of TCB}

The first constructed coincident index of U.S. economic activity was implemented by the Census Bureau, a task that was later transferred to The Conference Board (TCB) - a non-profit private entity whose main purpose is to do research on this field.

Since 1995, by order of the Department of Commerce of the U.S., TCB established a series of leading, coincident, and lagging indicators of economic activity. The coincident indicator is an average of the four coincident series - production, income, sales and employment. TCB uses a simple average of the standardized differenced (logged) series, which is a way of treating equally the fluctuations of all four series in computing the index. TCB approach is somewhat heuristic since it requires no estimation of a formal econometric model. Despite that, it works surprisingly well in practice; see the comparison in Issler and Vahid (2006) using the TCB index and alternative econometric-based indices in trying to replicate the NBER dating decisions.

The ideas behind TCB's method are twofold: simplicity and robustness. Simplicity is used because they weight information in coincident and leading indices with equal weights, once one control for the fact that different signals carry different information depending on their variance. One simple way to treat every series equally in this context is to standardize them, equally treating the standardized series. Robustness comes into play here since standardizing is a way of robustly treating different realizations of the same random variable.

The coincident series is an equally-weighted linear combination of four coincident series (income $\left(I_{t}\right)$, output $\left(Y_{t}\right)$, employment $\left(N_{t}\right)$, and sales $\left.\left(S_{t}\right)\right)$ once we control for the fact that the growth rate of these series have different variances. Hence, the coincident indicator uses weights constructed as:

$$
\Delta \ln \left(C I_{t}\right)=\frac{1}{4}\left[\frac{\Delta \ln \left(I_{t}\right)}{\sigma_{\Delta \ln (I)}}+\frac{\Delta \ln \left(Y_{t}\right)}{\sigma_{\Delta \ln (Y)}}+\frac{\Delta \ln \left(N_{t}\right)}{\sigma_{\Delta \ln (N)}}+\frac{\Delta \ln \left(S_{t}\right)}{\sigma_{\Delta \ln (S)}}\right]
$$

where $\sigma_{\Delta \ln (I)}, \sigma_{\Delta \ln (Y)}, \sigma_{\Delta \ln (N)}$ and $\sigma_{\Delta \ln (S)}$ are respectively the standard deviations of income, output, employment, and sales growth. It is straightforward to construct the level series $\ln \left(C I_{t}\right)$ or $C I_{t}$ once we possess $\Delta \ln \left(C I_{t}\right){ }^{1}$

\subsection{Back-casting}

In order to obtain similar series that are employed by The Conference Board (TCB) in constructing coincident indices (output, sales, income and employment) we were forced to back-cast various individual country series. In back-casting series, we followed Issler et al. (2012), who proposed a state-space procedure based on the interpolation method of Bernanke et al. (1997) and the extensions made by Mönch and Uhlig (2005). In both papers, the Kalman filter is used to interpolate GDP from quarterly to monthly frequency, where monthly auxiliary series help in estimating monthly GDP. Issler, Notini and Rodrigues back-cast the income and employment series of the Brazilian economy to compose a coincident index for Brazil for 1980-2009.

We start the discussion with the interpolation method of Bernanke, Gertler and Watson and Mönch and Uhlig. It is assumed that unobserved monthly GDP (labeled as $y_{t}^{+}$here) follows an $A R(p)$ process explained by pre-determined regressors $x_{t}$ and an $A R(1)$ error term. The term $x_{t}$ contains co-variates, which should have a high correlation with the series being interpolated: much of the contemporaneous behavior of the interpolated series comes from them. Also in $x_{t}$ are deterministic series such as a

\footnotetext{
${ }^{1}$ Equation (1) presents a simplified version of TCB's coincident index, which is, in fact, computed recursively, using a version of growth rates that are also growth-neutral regarding level increases and decreases.
} 
constant and/or seasonal dummies, which together with these co-variates, explain the behavior of $y_{t}^{+}$. The model for $y_{t}^{+}$has two equations:

$$
\begin{gathered}
\left(1-\phi_{1} L-\ldots-\phi_{p} L^{p}\right) y_{t}^{+}=x_{t} \beta+u_{t} \\
u_{t}=\rho u_{t-1}+\varepsilon_{t}
\end{gathered}
$$

Observed quarterly GDP (labeled as $y_{t}^{+}$here) is:

$$
\begin{gathered}
y_{t}=\sum_{i=0}^{2} y_{t-i^{\prime}}^{+} \quad t=3,6,9,12, \ldots \\
y_{t}=0, \text { otherwise. }
\end{gathered}
$$

Hence, quarterly GDP, which we can only observe on months $t=3,6,9,12$, etc., is the sum of the corresponding monthly GDPs in that quarter. Otherwise, it is just set to a fictional value of zero. Notice that setting $y_{t}=0$ for the months we do not observe GDP is a way of making quarterly GDP observable at the monthly frequency.

In the Kalman-filter literature for mixed frequency models, a fictional value is usually assumed for missing observations. Zero is the most frequent choice. However, the crucial step is to also impose that the fictional data has a very large variance, so that the zero value is discounted and overwritten by the Kalman-filter technique. This is exactly how Bernanke, Gertler, and Watson and Mönch and Uhlig proceed.

If we assume that the polynomial $\left(1-\phi_{1} L-\cdots-\phi_{p} L^{p}\right)$ is of order one, i.e., $p=1$, with coefficient $\phi$, the state-space form of Bernanke, Gertler, and Watson and Mönch and Uhlig's problem is the following:

$$
\begin{gathered}
\xi_{t}=\left(\begin{array}{c}
y_{t}^{+} \\
y_{t-1}^{+} \\
y_{t-2}^{+} \\
u_{t}
\end{array}\right)=\left(\begin{array}{cccc}
\phi & 0 & 0 & \rho \\
1 & 0 & 0 & 0 \\
0 & 1 & 0 & 0 \\
0 & 0 & 0 & \rho
\end{array}\right)\left(\begin{array}{c}
y_{t-1}^{+} \\
y_{t-2}^{+} \\
y_{t-3}^{+} \\
u_{t-1}
\end{array}\right)+\left(\begin{array}{c}
x_{t} \beta \\
0 \\
0 \\
0
\end{array}\right)+\left(\begin{array}{c}
\varepsilon_{t} \\
0 \\
0 \\
\varepsilon_{t}
\end{array}\right) \\
y_{t}=\mathbf{H}_{t}^{\prime} \xi_{t},
\end{gathered}
$$

where (4) and (5) are respectively the state and the observation equations and the matrix $\mathbf{H}_{t}^{\prime}$ is timevarying, with the following format:

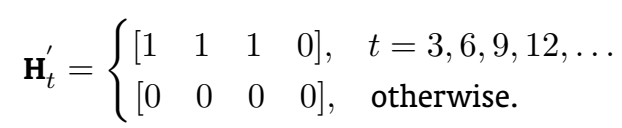

One interesting feature of their approach is that it encompasses several data interpolation models. To assess the quality of interpolation, Bernanke, Gertler, and Watson propose the use two $R^{2}$ measures of fit. Denoting by $\widehat{y_{t \mid T}^{+}}$the smoothed estimate of monthly GDP, and by $\widehat{u_{t \mid T}}$ the same estimate of the error term $u_{t}$, they consider:

$$
\begin{aligned}
& R_{\text {level }}^{2}=\frac{\operatorname{VAR}\left(\widehat{y_{t \mid T}^{+}}\right)}{\operatorname{VAR}\left(\widehat{y_{t \mid T}^{+}}\right)+\operatorname{VAR}\left(\widehat{u_{t \mid T}}\right)}, \text { and, } \\
& R_{\text {diff }}^{2}=\frac{\operatorname{VAR}\left(\widehat{\Delta y_{t \mid T}^{+}}\right)}{\operatorname{VAR}\left(\widehat{\Delta y_{t \mid T}^{+}}\right)+\operatorname{VAR}\left(\widehat{\Delta u_{t \mid T}}\right)}
\end{aligned}
$$


Bernanke, Gertler, and Watson claim that it is more informative to report the $R^{2}$ in first differences since the same statistic in levels will always be close to unity.

Issler et al. (2012) adapt the state-space representation in (4) and (5) to the problem of back-casting a series for which we observe part of its realizations, but not all, and where both the target variable as well as the covariates are in the same frequency (monthly, in our case). In some sense, this is quite close to the problem worked out in Bernanke, Gertler and Watson and Mönch and Uhlig. Issler, Notini and Rodrigues follow their solution, setting to zero all the missing observations to be back-cast, also imposing that the fictional data has a very large variance.

The details of the back-casting method are as follows: suppose we possess a total of $t=1,2, \ldots, T^{*}, \ldots, T$, observations on $x_{t}$. However, for series $y_{t}^{+}$, we only possess data from $t=$ $T^{*}+1, \ldots, T$, with missing values from $t=1,2, \ldots, T^{*}$. Let the order of the polynomial $\left(1-\phi_{1} L-\right.$ $\left.\cdots-\phi p L^{p}\right)$ to be unity, i.e., $p=1$, with coefficient $\phi$, recalling that now we need not impose the time-aggregation restriction in (5). The state-space form of our problem collapses to the following:

$$
\begin{gathered}
\xi_{t}=\left(\begin{array}{c}
y_{t}^{+} \\
u_{t}
\end{array}\right)=\left(\begin{array}{ll}
\phi & \rho \\
0 & \rho
\end{array}\right)\left(\begin{array}{c}
y_{t-1}^{+} \\
u_{t-1}
\end{array}\right)+\left(\begin{array}{c}
x_{t} \beta \\
0
\end{array}\right)+\left(\begin{array}{c}
\varepsilon_{t} \\
\varepsilon_{t}
\end{array}\right) \\
y_{t}=\mathbf{H}_{t}^{\prime} \xi_{t},
\end{gathered}
$$

where (7) and (8) are respectively the state and the observation equations and the matrix $\mathbf{H}_{t}^{\prime}$ is timevarying, with the following form:

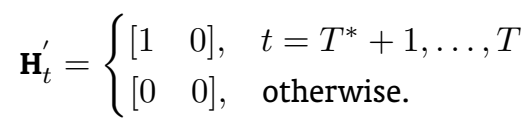

Notice that the back-cast problem is simpler than the interpolation problem, since we do not have to impose high- to low-frequency constraints in the data which are present in (5). The key to the problem lies in the choice for $\mathbf{H}_{t}^{\prime}$ in (8). Issler, Notini and Rodrigues make the latent variable $y_{t}^{+}$identical to $y_{t}$ for the periods in which the latter is observed (notice that there is no error term in (8)). This has two consequences. First, the algorithm will forecast $y_{t}^{+}$to be identical to $y_{t}$ for $t=T^{*}+1, \ldots, T$. Second, it will use the available data to estimate a model and will use this model to forecast the latent variable in the periods in which it is not observable, i.e., from $t=1,2, \ldots, T^{*}$. Under correct specification, this model can produce the optimal forecasts of the latent variable consistent with all available future information. That will be simply given by the smoothed forecast of $y_{t}^{+}$, i.e., by $\widehat{y_{t \mid T}^{+}}$.

\section{EMPIRICAL RESULTS}

\subsection{The Coincident Series}

An important part of this paper is the choice of variables to be included in the coincident indicator for specific Latin American countries, namely: Argentina, Brazil, Chile, Colombia and Mexico. As stressed earlier, a major difficulty in this line of research for Latin America is the scarcity of reliable databases with long time series.

We follow Issler et al. (2012) to back-cast some of the coincident series for each country. Back-casting was conducted in two steps. First we selected the covariate series, which could potentially explain the variations of the target series. In some back-casting equations we used the monthly GDP as an auxiliary variable. Whenever that was the case, monthly GDP data were estimated following Issler and Notini (2008) interpolation method. 
If necessary, all coincident series used in this paper are extended to cover the period from January 1980 to June 2012 on a monthly basis. They were also were seasonally adjusted using the X-12 procedure. Details about the data used in the paper, the co-variates series with their sources and the $R^{2}$ measures of fit can be found in Tables 1, 2, 3 and A-11 in the Appendix.

After obtaining the four coincident series for each country, three tests unit-root tests were applied and results are shown in Table 4 in Appendix. All series showed signs of unit roots in the tests and were consequently transformed into first differences $(\log s)$ prior to the combination that led to the indexes.

In order to validate the coincident indices, and consequently the back-casting procedure adopted here, we compared the dating results for each country coincident index with that of its quarterly GDP. Datings were obtained by applying the Bry and Boschan (1971) algorithm as modified in Harding and Pagan (2002). States of the economy for the GDP and the coincident index were compared based on a variant of the Quadratic Probability Score (QPS) proposed by Diebold and Rudebusch (1989). ${ }^{2}$ As the Appendix shows, the results were very similar, attesting the quality of the interpolation procedure adopted here, and, consequently, the quality of our coincident indicators.

\subsection{Argentina}

Argentina is a tough case, since none of the four coincident series were available on a monthly basis from January 1980 to June 2012. We used industrial production data from the Monthly Survey of Manufacture, released by Argentina's National Institute of Statistics and Censuses (INDEC), available since 1994. This index is available for the entire industrial sector.

Employment data is particularly scarce in Argentina, since the broader series which covers the whole economy is available only quarterly since 2003. Longer series are available only in terms of the percentage of employed persons, and most of the sample only on a semiannual basis. Thus, the solution to approximate the number of employed people was to use the monthly number of employees in the supermarket sector, released by the INDEC since January 1997.

As a measure of income, we used an index of private nominal wages, which is extracted from the INDEC and constructed as a weighted average of indicators of the formal and the informal sectors. For the real income measure, the nominal index was deflated by the consumer prices index. Although the series is short as it is available since October 2001, it is the only indicator that displays a broad income measure of the economy.

In the case of an absent aggregate indicator of retail sales for the entire economy, we used data from INDEC's Encuesta de Centros de Compras (Shopping Centers Survey), which covers thirty shopping centers since January 1997, about 50\% of which are located in Buenos Aires.

To back-cast the coincident series, we used an auxiliary variable to interpolate GDP (Issler and Notini, 2008) to monthly frequency: the volume of monthly sales of cement provided by Association of Portland Cement since 1980. Those two series, interpolated GDP and cement sales, were then used as covariates in back-casting the series in the coincident index.

All four Argentina coincident series are plotted in Figure 1, which includes the results of the backcast series. The non-shaded areas in the graphs depict the actual sample in which we observe them.

\footnotetext{
${ }^{2}$ The Quadratic Probability Score, labeled as QPS, is given by:

$$
Q P S=\frac{\sum_{t=1}^{T}\left(P_{t}-R_{t}\right)^{2}}{T}
$$

where $P_{t}$ denotes the predicted state outcomes from a candidate indicator (coincident indicator) and $R_{t}$ denotes the observed state outcome of the reference series (GDP). Both are equal to one for a recession and zero otherwise; $T$ is the total number of sample observations. By construction, the value of QPS ranges between zero and one, with zero indicating a perfect fit for the state of the economy of the reference.
} 


\section{r $\mathbf{b}$ Constructing Coincident Indices of Economic Activity for the Latin American Economy}

Figure 1: Argentina's Coincident Series

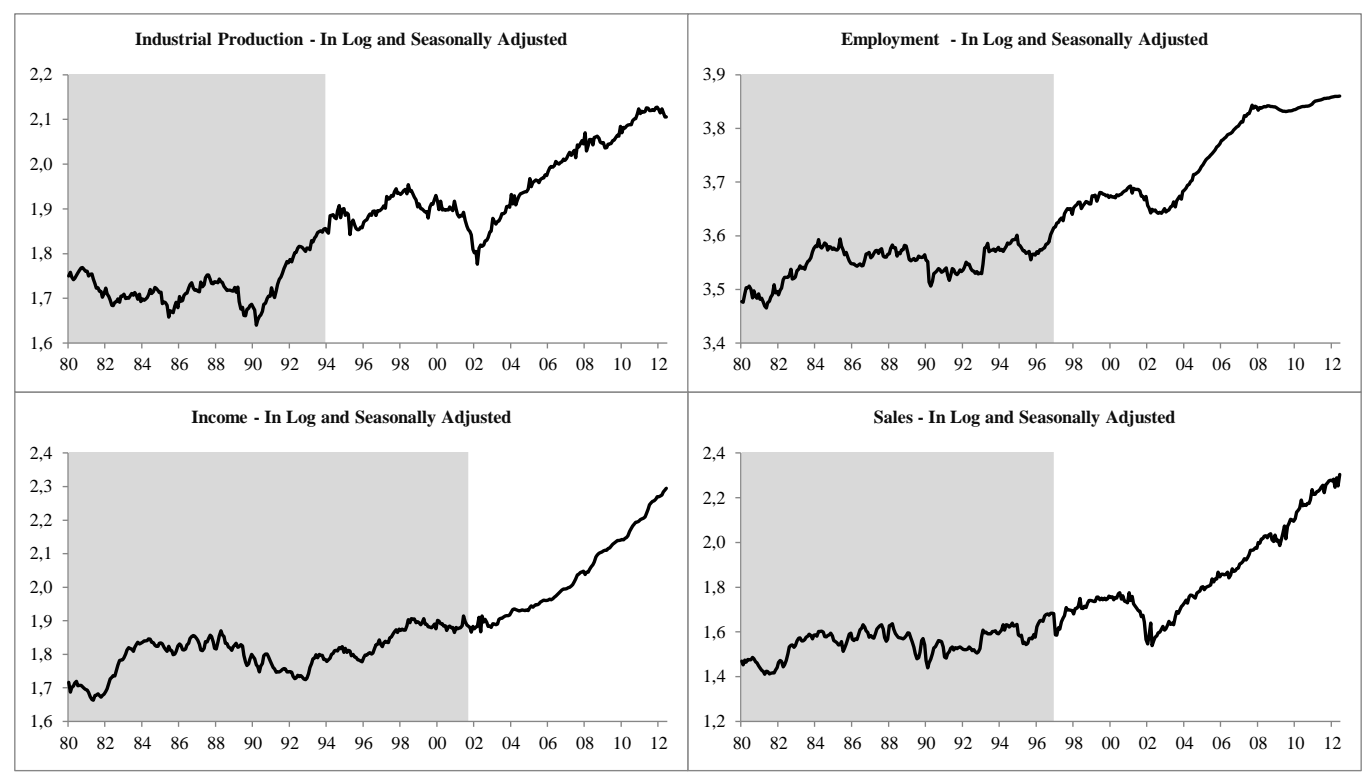




\subsection{Brazil}

Here we follow Issler et al. (2012) in constructing our coincident series. The only difference regarding their work is that we update the data of their paper until June 2012 since their index had been only computed until November 2007. For output, we use industrial production computed by IBGE available from January 1980. As there is not a long span of sales series in Brazil, we thus use total Brazilian production of corrugated paper, which is computed by ABPO, as a proxy for sales. The employment measure is the total number of persons - 10 years old and above - who have a job according to IBGE's Monthly Employment Survey, available since March 2002. The real income series, extracted from the same Survey, work as a proxy for income. The coincident series are plotted in Figure 2, which includes the results of the back-cast series. The non-shaded areas in the graphs depict the actual sample in which we observe them.

Figure 2: Brazil's Coincident Series

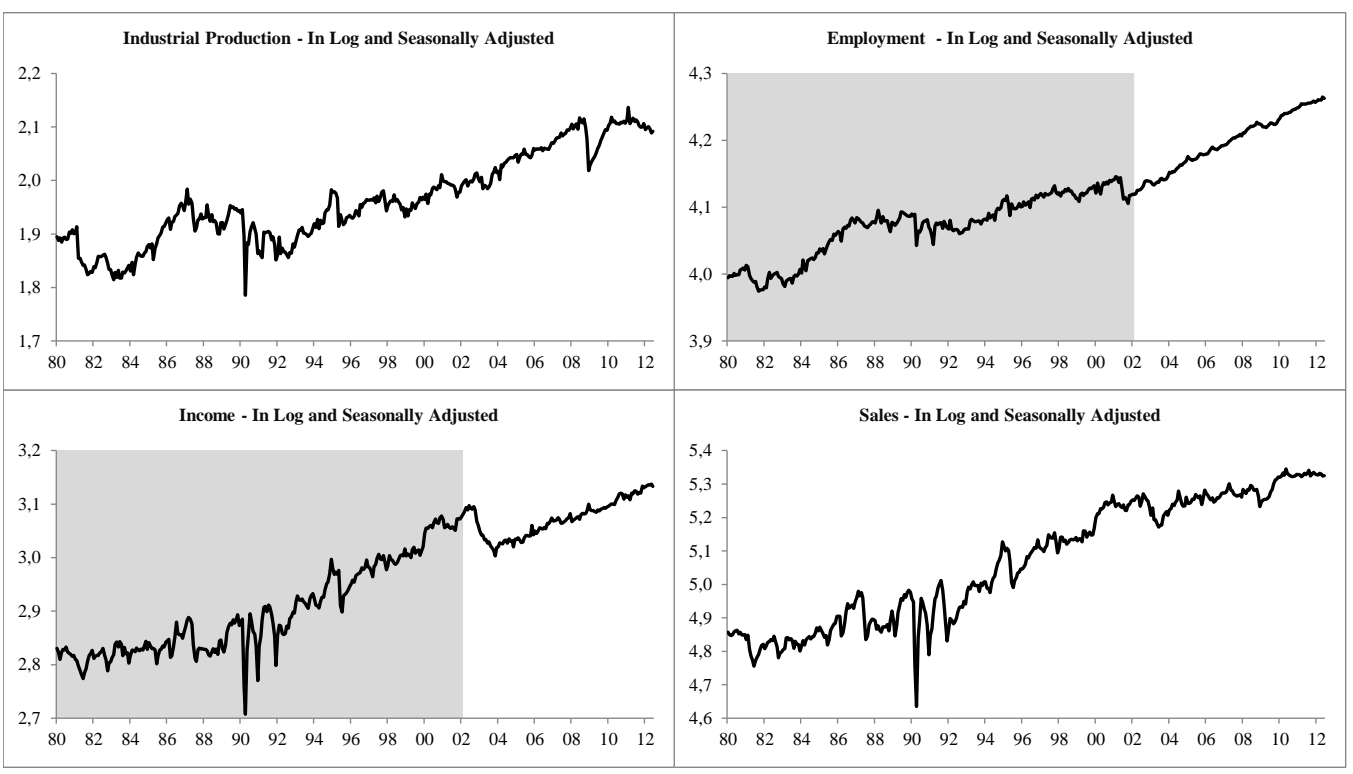




\subsection{Chile}

For employment, the general indicator of employment in the economy is used, available from January 1986. For back-casting this series, the manufacturing employment series is used - available from the International Financial Statistics (IFS) database of the International Monetary Fund. In the case of income, we employ an index of real compensation per hour series published by the National Institute of Statistics (INE), which is available from April 1993. To back-cast it, we use as auxiliary variables the monthly GDP (Issler and Notini, 2008), employment in the manufacturing sector, and the industrial production index, both available since 1980 in the IMF database.

Retail sales, released by the "Camara Nacional del Comercio" (National Commerce Chamber) of Chile, is used as the sales proxy. It is available on a monthly basis since January 1991. To back-cast it, we chose as covariates monthly GDP and the employment in the manufacturing sector.

The industrial production index published by INE is available only since 1991. However, the IMF provides a monthly production series available since 1980 that was used as co-variate in the backcasting procedure.

The coincident series are plotted in Figure 3, which includes the results of the back-casted series. The non-shaded areas in the graphs depict the actual sample in which we observe them.

Figure 3: Chile's Coincident Series

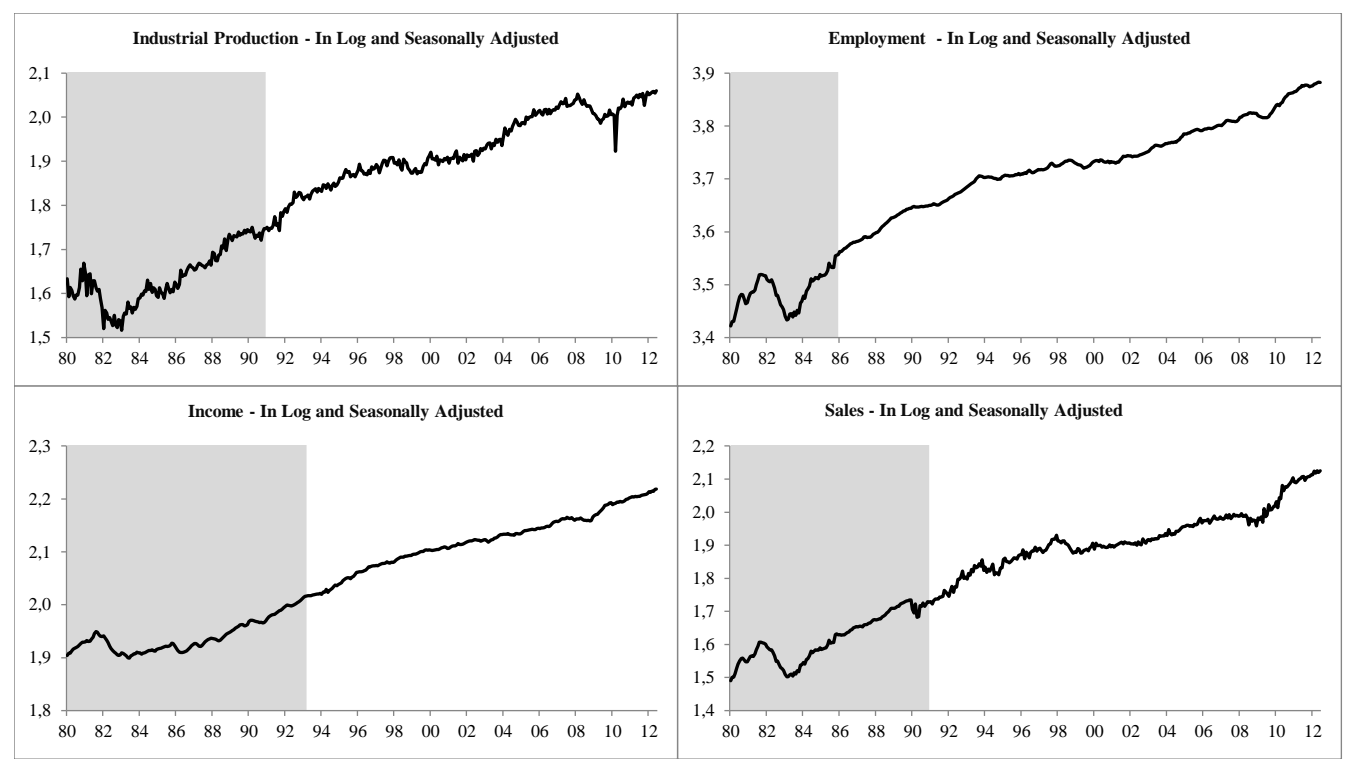




\subsection{Colombia}

In the case of Colombia, the industrial production and income series were extracted from the Monthly Manufacturing Survey. The first series has been available since 1980, whereas the real income variable is available from 1990. The measure of retail sales is based on the Muestra Mensual de Comercio al por Menor (Monthly Retail Survey), which represents the actual sales excluding the share of fuel sales. The employment series is based on the total employment in the economy, which is monthly released in the Household Survey since 2001. All four series are published monthly by the National Administrative Department of Statistics (DANE).

To back-cast the employment and sales series, we used as covariates the industrial production index and the real imports of consumer and capital goods released monthly by DANE. The coincident series are plotted in Figure 4, which includes the results of the back-cast series. The non-shaded areas in the graphs depict the actual sample in which we observe them.

Figure 4: Colombia's Coincident Series

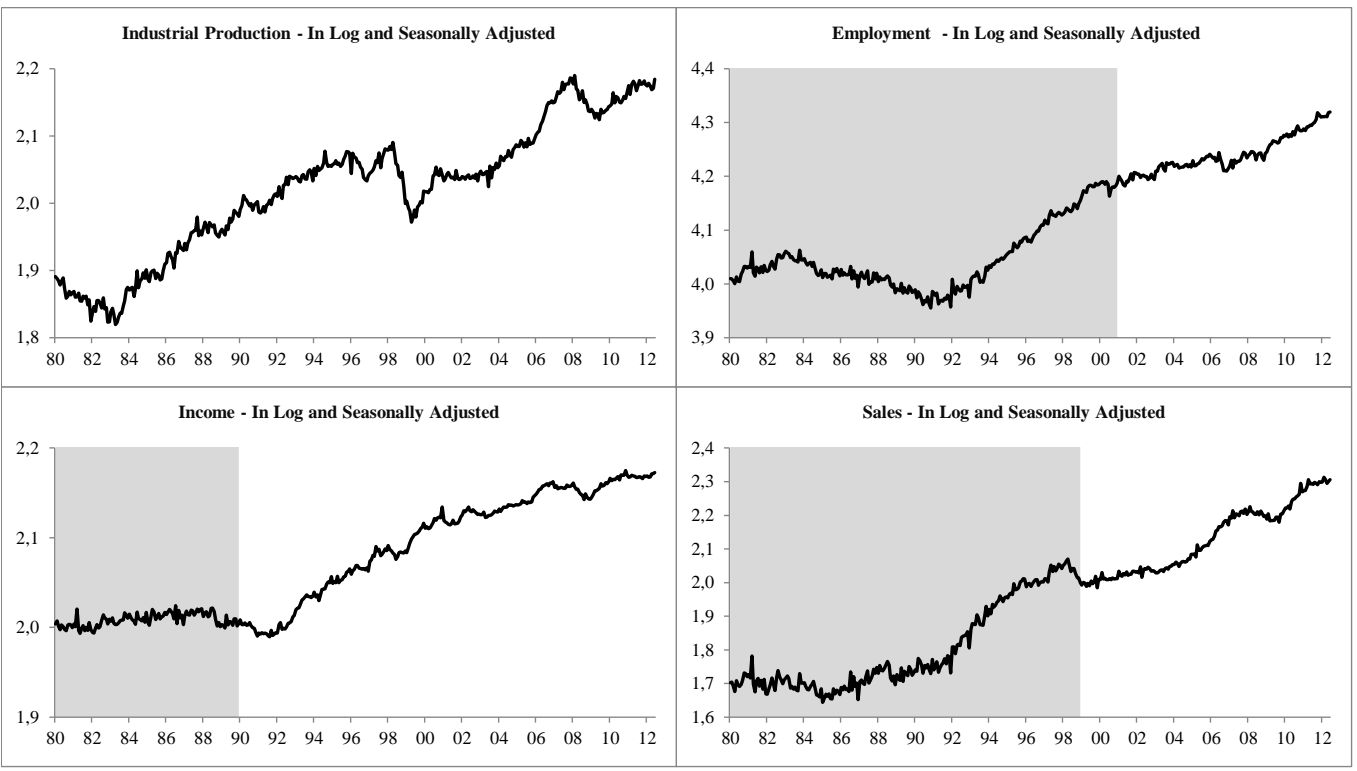




\section{rbe}

\subsection{Mexico}

The National Institute of Statistics and Geography (INEGI) releases a monthly coincident indicator, similar to the TCB index. In this work, we estimate the INEGI index from 1980.

The industrial production and nominal income series are available since 1980 in the INEGI's Monthly Industrial Survey. In the second series, the monthly Consumer Price Index released by INEGI was employed to deflate the nominal income and build the real income series. As in the Mexican case, there is not a broad survey of employment that covers the whole economy monthly. Therefore, the Insured Workers index, released since 1994 by the Secretary of Labor and Social Commercial Establishments was used. These last two series were back-casted.

To back-cast the series, we used the industrial production series, the income series and the interpolated monthly GDP (Issler and Notini). The coincident series are plotted in Figure 5, which includes the results of the back-casted series. The non-shaded areas in the graphs depict the actual sample in which we observe them.

Figure 5: Mexico's Coincident Series

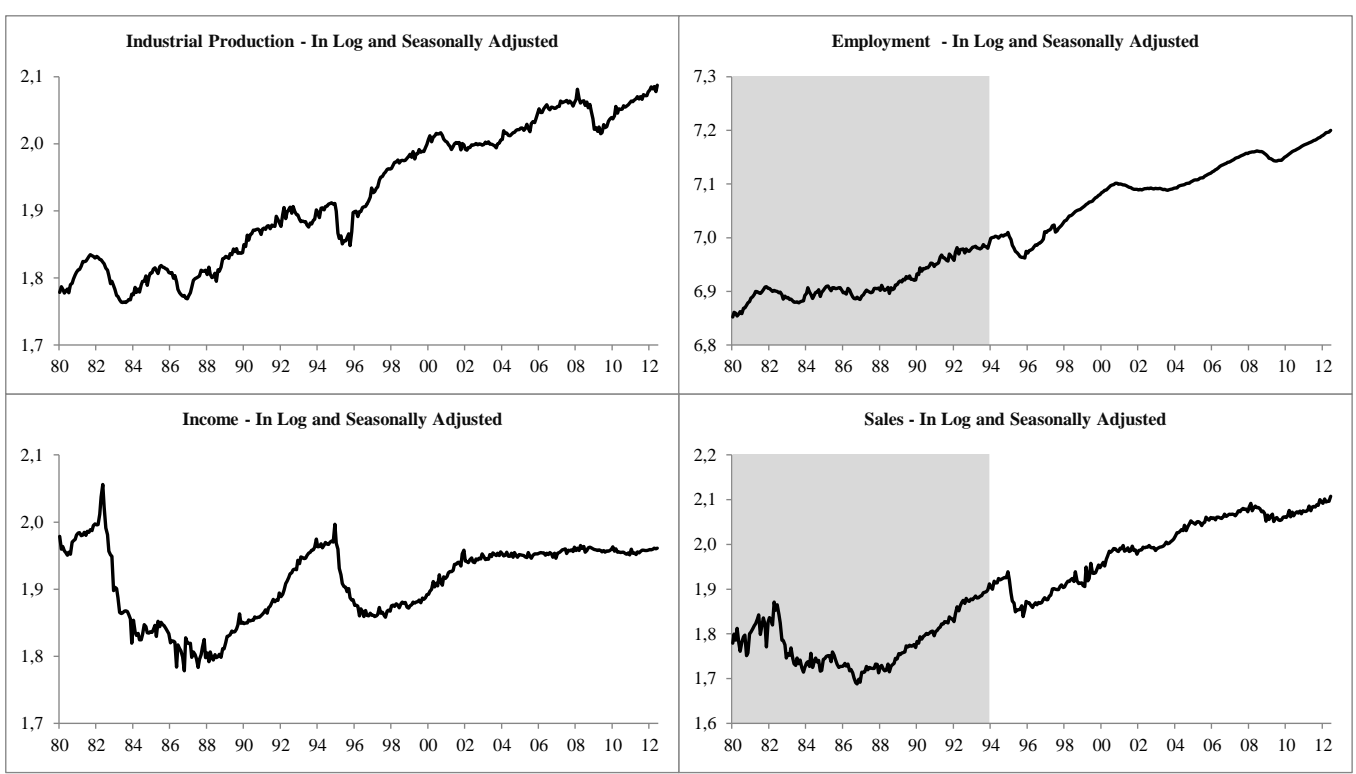




\section{THE COINCIDENT INDICATOR}

For each country, using the now available coincident series from 1980 through 2012, we constructed a coincident index using equation (1). Then, the turning points of each-country composite index was detected using the Bry and Boschan (1971) dating algorithm.

\subsection{Argentina}

In the case of Argentina, we have 7 recessions in the period, averaging one recession every 4.6 years. The average duration of the recessions is 12.7 months, one of the highest among the countries analyzed. Figure 7 shows the coincident indicator, with shaded areas depicting recession periods.

Figure 6: Argentina Coincident Index

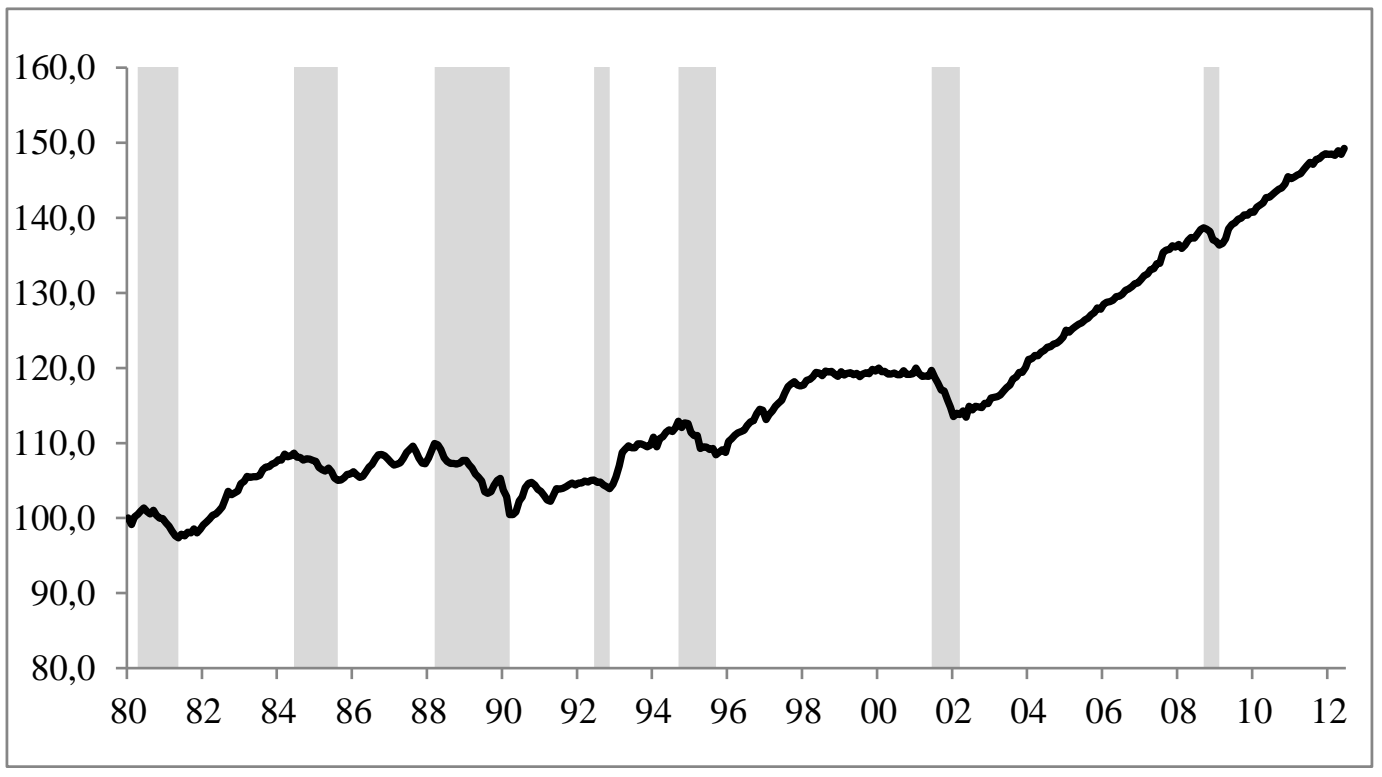

Table 1 lists Argentina's recessions from 1980:1 to 2012:06 when turning points dating is made using Bry and Boschan's technique.

Table 1: Turning Points - Argentina

\begin{tabular}{cccc}
\hline Peak Dates & Through Dates & Duration (months) & Amplitude \\
\hline 1980:04 & $1981: 05$ & 14 & 3.14 \\
$1984: 06$ & $1985: 08$ & 15 & 3.59 \\
1988:03 & $1990: 03$ & 25 & 9.49 \\
1992:06 & $1992: 11$ & 6 & 1.12 \\
$1994: 09$ & $1995: 09$ & 13 & 4.49 \\
$2001: 06$ & $2002: 03$ & 10 & 6.24 \\
$2008: 09$ & $2009: 02$ & 6 & 2.31 \\
\hline
\end{tabular}




\section{rbe}

\subsection{Brazil}

Brazil has the highest number of recessions of all Latin-American countries analyzed here: a total of ten. On the other hand, the average length of these recessions is low: 10.6 months. In other words, Brazil had shorter cycles (expansions and recessions), but are more frequent. Figure 7 presents the Brazilian coincident indicator. On average, Brazil had one recession every three years.

Figure 7: Brazil Coincident Index

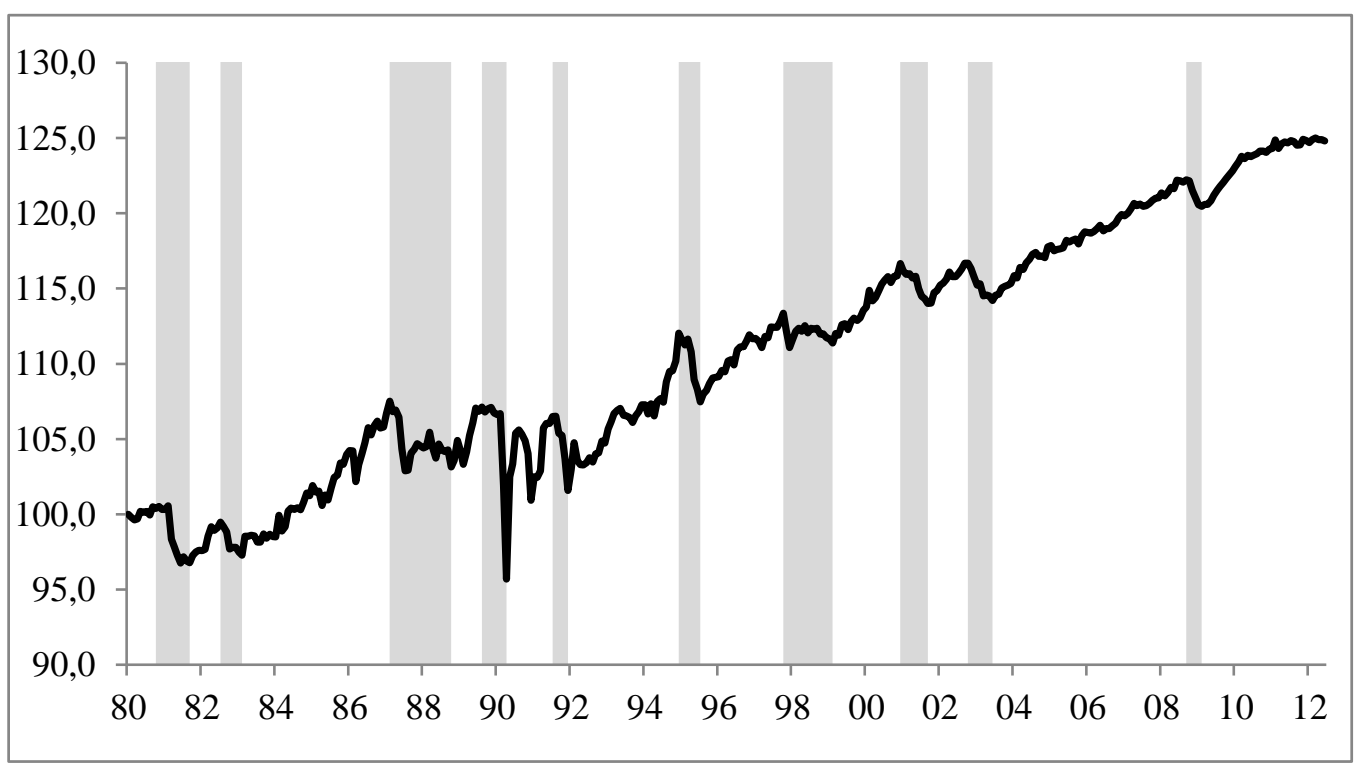

The turning points of Brazilian business cycles are summarized in Table 2.

Table 2: Turning Points - Brazil

\begin{tabular}{cccc}
\hline Peak Dates & Through Dates & Duration (months) & Amplitude \\
\hline $1980: 10$ & $1981: 09$ & 12 & 3.63 \\
$1982: 07$ & $1983: 02$ & 8 & 2.2 \\
$1987: 02$ & $1988: 10$ & 21 & 4.38 \\
$1989: 08$ & $1990: 04$ & 9 & 11.43 \\
$1991: 07$ & $1991: 12$ & 6 & 4.92 \\
$1994: 12$ & $1995: 07$ & 8 & 4.56 \\
$1997: 10$ & $1999: 02$ & 17 & 1.98 \\
$2000: 12$ & $2001: 09$ & 10 & 2.66 \\
$2002: 10$ & $2003: 06$ & 9 & 2.48 \\
$2008: 09$ & $2009: 02$ & 6 & 1.76 \\
\hline
\end{tabular}




\subsection{Chile}

The Chilean economy has the smoother trend growth among all countries analyzed here. During the more than 32 years we focus on, there were four recessions lasting about 12 months each. However, there was only one severe recession, as Figure 8 shows.

\section{Figure 8: Chile Coincident Index}

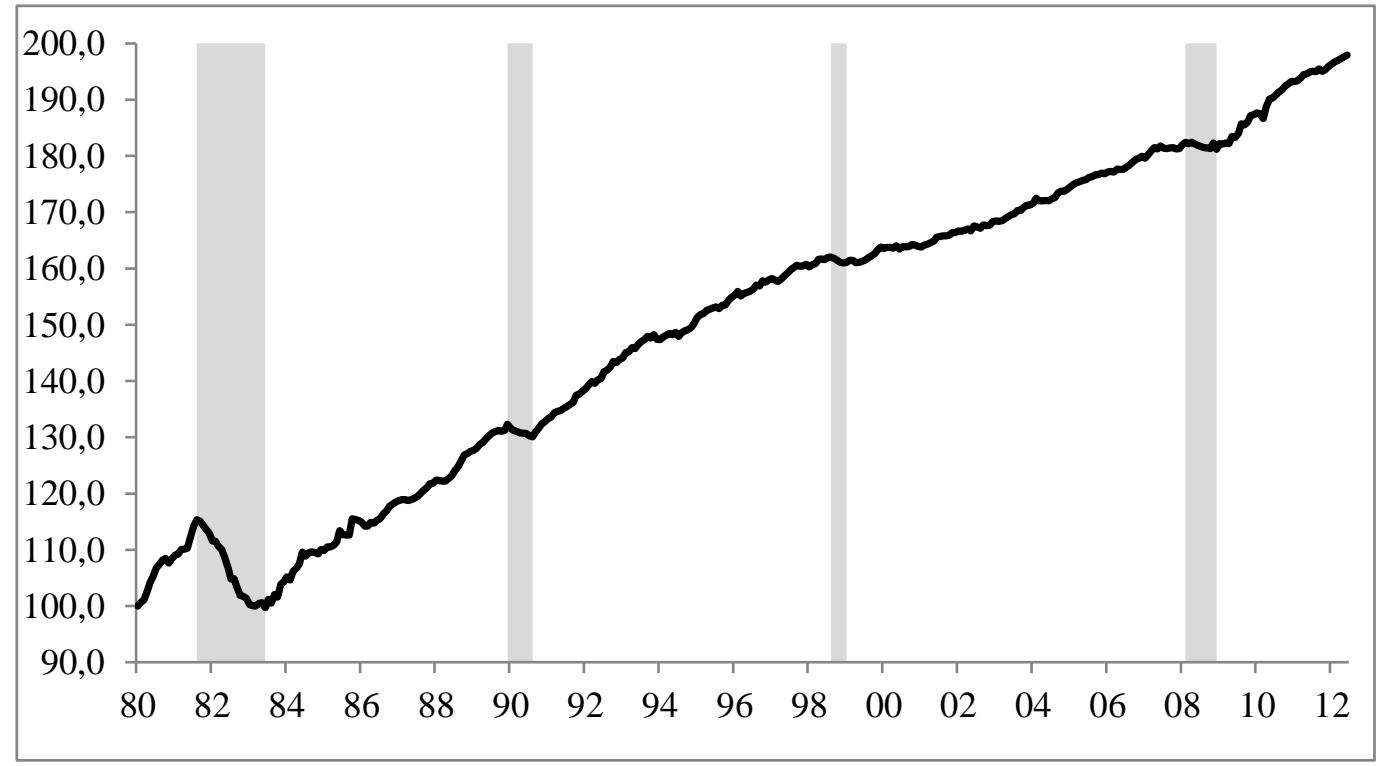

The turning points are summarized in Table 3.

Table 3: Turning Points - Chile

\begin{tabular}{cccc}
\hline Peak Dates & Through Dates & Duration (months) & Amplitude \\
\hline 1981:08 & $1983: 06$ & 23 & 15.62 \\
$1989: 12$ & $1990: 08$ & 9 & 2.21 \\
$1998: 08$ & $1999: 01$ & 6 & 0.98 \\
$2008: 02$ & $2008: 12$ & 11 & 1.22 \\
\hline
\end{tabular}




\section{rbe}

\subsection{Colombia}

The Colombian economy showed eight recessions from 1980 to 2012, with an average of one recession every four years. Among the analyzed countries, Colombia was the economy with the lowest average recession duration: 10 months. Figure 9 shows the coincident indicator, where the shaded areas correspond to the recession's periods.

Figure 9: Colombia Coincident Index

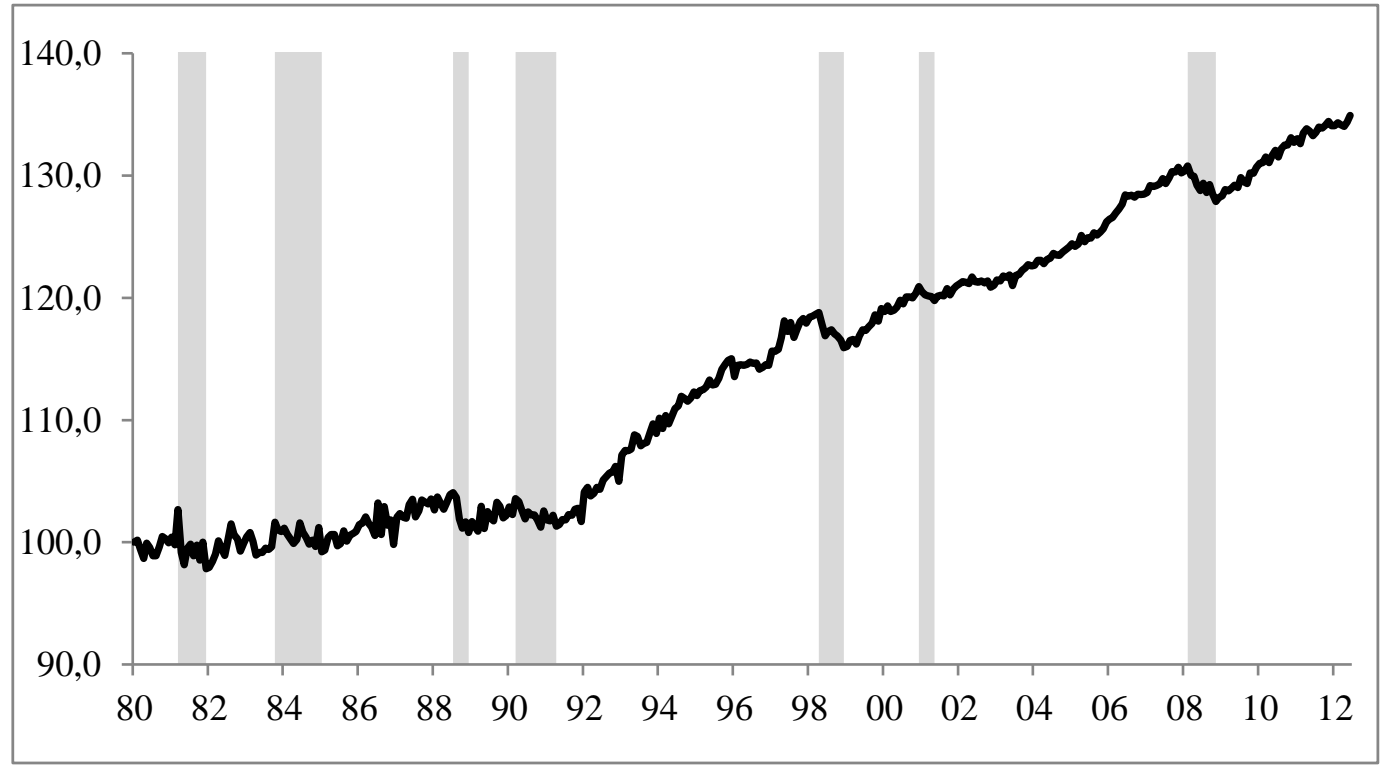

The Colombia turning points are summarized in Table 4.

Table 4: Turning Points - Colombia

\begin{tabular}{cccc}
\hline Peak Dates & Through Dates & Duration (months) & Amplitude \\
\hline 1981:03 & $1981: 12$ & 10 & 4.85 \\
1983:10 & $1985: 01$ & 16 & 2.43 \\
1988:07 & $1988: 12$ & 6 & 3.27 \\
$1990: 03$ & $1991: 04$ & 14 & 2.25 \\
$1998: 04$ & $1998: 12$ & 9 & 2.87 \\
$2000: 12$ & $2001: 05$ & 6 & 1.13 \\
$2008: 02$ & $2008: 11$ & 10 & 2.91 \\
\hline
\end{tabular}




\subsection{Mexico}

The Mexican economy shows the highest average recession's duration among the countries analyzed. From 1980 to 2012, six recessions were recorded, which lasted 14.5 months, on average. Figure 10 shows the coincident indicator, where recessions periods are depicted by shaded areas.

\section{Figure 10: Mexico Coincident Index}

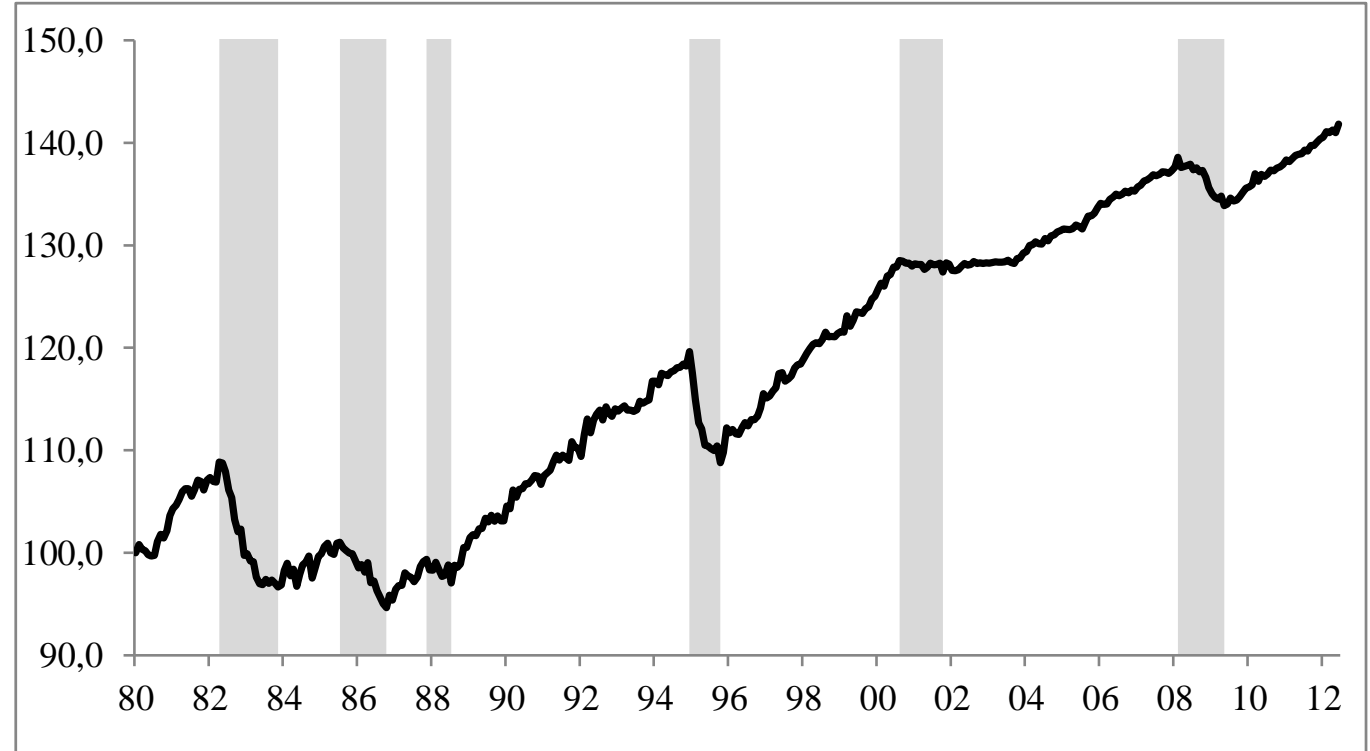

Mexico's turning points are summarized in Table 5.

Table 5: Turning Points - Mexico

\begin{tabular}{cccc}
\hline Peak Dates & Through Dates & Duration (months) & Amplitude \\
\hline 1982:04 & $1983: 11$ & 20 & 12.18 \\
1985:07 & $1986: 10$ & 16 & 6.39 \\
$1987: 11$ & $1988: 07$ & 9 & 2.29 \\
$1994: 12$ & $1995: 10$ & 11 & 10.85 \\
$2000: 08$ & $2001: 10$ & 15 & 1.12 \\
$2008: 02$ & $2009: 05$ & 16 & 4.69 \\
\hline
\end{tabular}




\subsection{Latin America}

After building and analyzing each country indicators, we propose a Latin America aggregate indicator, where each country was weighted by their respective standard deviation, using the idea behind equation (1). Figure 11 shows the Latin America indicator, where shaded areas depict recession periods.

Figure 11: Latin America Coincident Index

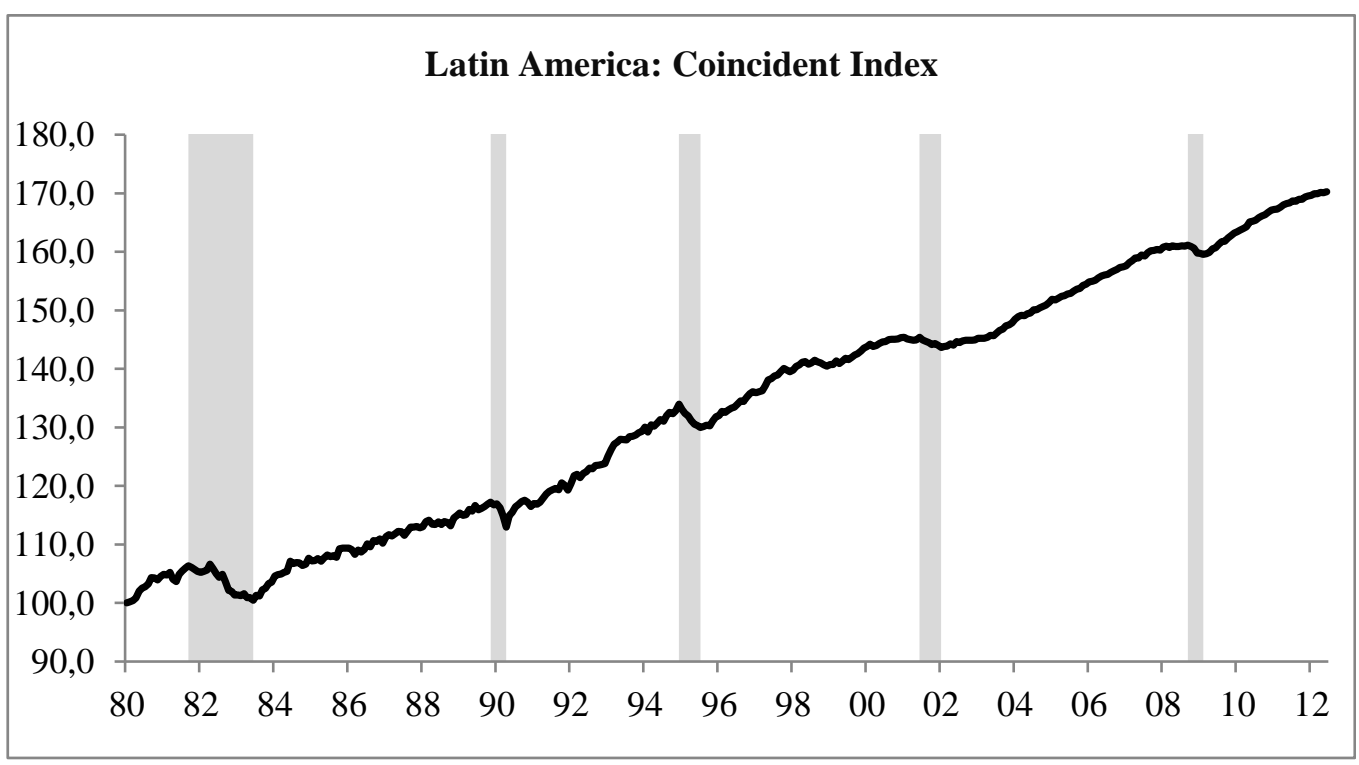

There were common recession periods in the early 1980's, where several countries faced balance of payments problems as a result of fixed exchange rate regimes combined to the global financial instability brought by the two oil shocks. Another region common recession period was the one followed by the Mexican crisis, which hit many emerging economies due to the confidence crisis and increased investor risk aversion. Finally, the 2000-02 recessions impact most countries due to the global nature of the crisis, which started with the bursting of the technology sector bubble.

Regarding the 2008 global financial crisis, the Mexican economy was the most affected because of its heavy dependence on the U.S. economic cycle. However, all the economies in the region suffered with the global slowdown after a while. Despite that, at the beginning of the 2008 crisis, which first hit first the more mature economies, some authors believed that emerging economies would decouple from advanced economies. This proved to be wrong, but only after a while. It is relevant to test empirically whether there is any relationship between the Latin America coincident indicator and the United States indicator. Both are presented in Figure 12.

We now examine whether there is Granger-causality between the coincident index of the U.S. (TCB) and our Proposed Latin-American coincident index. The two do not cointegrate. Thus, we take the firstdifference of the two series prior to performing Granger-causality tests using the Sims version of the test. The lag length chose were 3 and 6, both are optimally chosen by different information criteria. The results are clear: the U.S. coincident indicator Granger-causes the Latin-American coincident indicator, but it is not Granger-caused by it. This means that the U.S. index is a good leading indicator for Latin American economic activity. 


\section{Figure 12: US and Latin America Coincident Indexes}

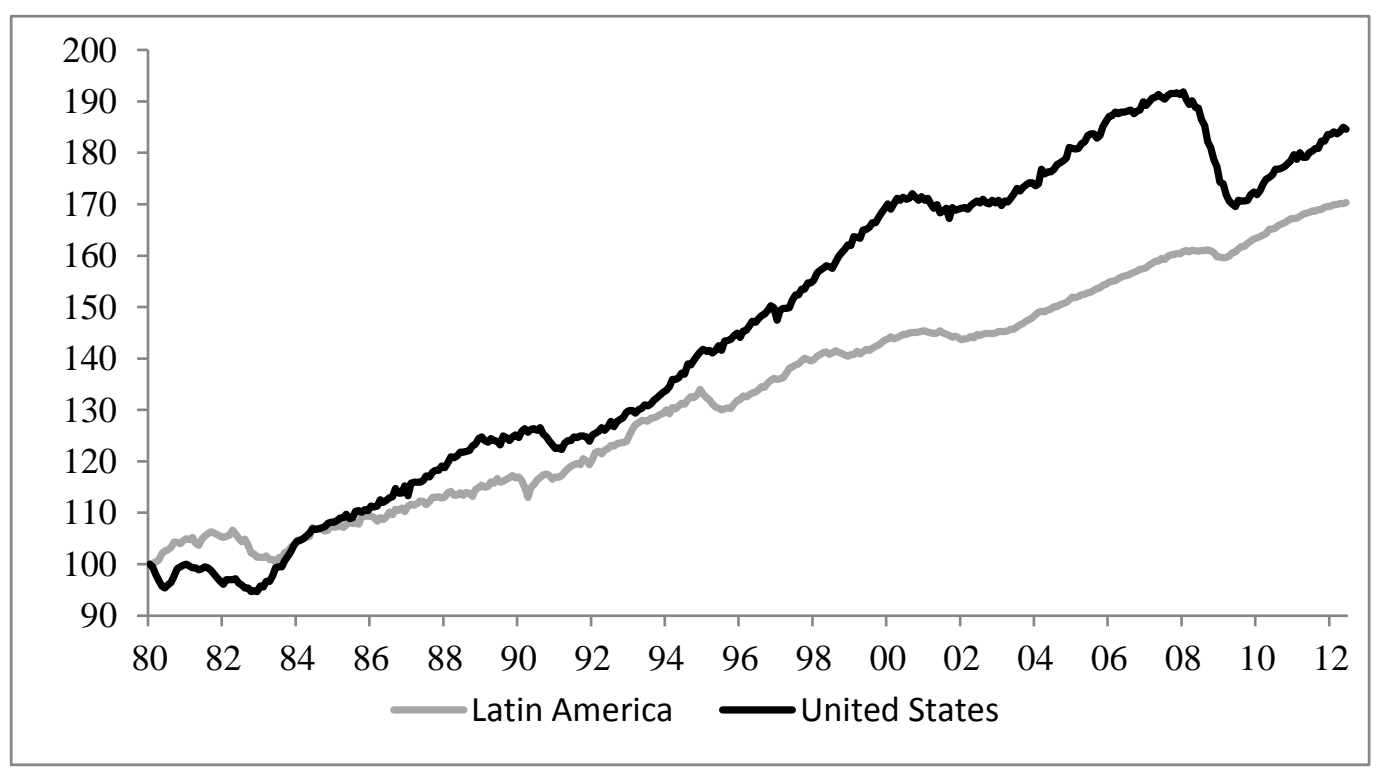

\subsubsection{Business Cycle Synchronization}

Finally, we investigate the degree of business-cycle synchronization across the Latin-American countries applying the Concordance Index (CI) proposed by Harding and Pagan (2002). The CI measures the degree of co-movement between one country/region specific cycle $\left(y_{j t}\right)$ and other country/region cycle $\left(y_{r t}\right)$. It counts the fraction of time both series are simultaneously in the same state of expansion $\left(S_{t}=1\right)$ or contraction $\left(S_{t}=0\right)$. Mathematically, for a total of $n$ periods, we compute the concordance index to be:

$$
I_{j r}=n^{-1}\left[\#\left\{S_{j t}=1, S_{r t}=1\right\}\right]+n^{-1}\left[\#\left\{S_{j t}=0, S_{r t}=0\right\}\right]
$$

If two cycles are exactly pro-cyclical then the index would be unity, while a value of zero marks it down as being exactly counter-cyclical. We compute the $\mathrm{CI}$ for each pair of countries and summarize the main results in Table 6 . As could be noted, the Latin America countries cycles showed a high degree of co-movement ( $\mathrm{CI}$ on average above 0.70 in all the cases covered). 
Table 6: Harding and Pagan (2002) Concordance Index

\begin{tabular}{lcccccc}
\hline & Argentina & Brazil & Chile & Colombia & Mexico & Latin America \\
\hline Argentina & 1 & 0.72 & 0.69 & 0.70 & 0.69 & 0.78 \\
Brazil & & 1 & 0.73 & 0.71 & 0.72 & 0.77 \\
Chile & & & 1 & 0.83 & 0.78 & 0.91 \\
Colombia & & & & 1 & 0.78 & 0.74 \\
Mexico & & & & & 1 & 0.82 \\
Latin America & & & & & & 1 \\
\hline
\end{tabular}

\section{CONCLUSION}

This paper has three main contributions. The first is to propose a coincident indicator for specific Latin American countries: Argentina, Brazil, Chile, Colombia and Mexico.

In order to obtain similar series to those defined by The Conference Board (TCB) when constructing coincident indices (output, sales, income and employment), we chose to back-cast various individual country series. When back-casting, we followed Issler et al. (2012), who proposed a state-space procedure based on the interpolation method of Bernanke et al. (1997) and the extensions made by Mönch and Uhlig (2005).

The second contribution is to establish a chronology of recessions for these countries, covering the period from 1980 to 2012 on a monthly basis. These results are validated comparing the quarterly chronology of recessions using official GDP data and the coincident series constructed. The last contribution is to propose an aggregate indicator for the Latin American economy, weighting the individual composite indicators for the five countries analyzed here.

The composite regional index for Latin America tracks reasonably well its economic activity, although not all countries follow the behavior of the composite index. For the countries surveyed, on average, recessions are more frequent than in the U.S., the only exception being Chile. Regarding the magnitude of the 2007/2008 global financial crisis, all five countries were affected. Finally, a chronology of recessions in Latin America was established and the Latin-American cycles were compared to the U.S. business cycles, finding that the U.S. cycle Granger-causes the Latin American cycle but it is not caused by it. 


\section{BIBLIOGRAPHY}

Aiolfi, M., Catão, L., \& Timmerman, A. (2011). Common factor in Latin America's business cycles. Journal of Development Economics, 95(2):212-228.

Artis, M. J., Kontolemis, Z. G., \& Osborn, D. R. (1997). Business cycles for G7 and European countries. Journal of Business, 70(2):249-279.

Backus, D. \& Kehoe, P. (1992). International evidence on the historical properties of business cycles. American Economic Review, 82:864-888.

Bernanke, B., Gertler, M., \& Watson, M. (1997). Systematic monetary policy and the effects of oil price shocks. Brookings Papers on Economic Activity, pages 91-157.

Boldin, M. D. (1994). Dating turning points in the business cycles. Journal of Business, 67(1):97-130.

Bry, G. \& Boschan, C. (1971). Cyclical Analysis of Time Series: Selected Procedures and Computer Programs. Columbia University Press, New York.

Burns, A. F. \& Mitchell, W. C. (1946). Measuring Business Cycles. National Bureau of Economic Research, New York.

Calvo, G. A., Leiderman, L., \& Reinhart, C. (1992). Capital inflows and real exchange rate appreciation in Latin America: The role of external factors. IMF Staff Papers, 40(1):108-151.

Chauvet, M. (1998). An econometric characterization of business cycle dynamics with factor structure and regime switching. International Economic Review, 39:969-996.

Chauvet, M. (2001). A monthly indicator of Brazilian GDP. Brazilian Review of Econometrics, 21:1-48.

Chauvet, M. (2002). The Brazilian business cycle and growth cycles. Revista Brasileira de Economia, 56:75-106.

Chauvet, M., Lima, E., \& Vasquez, B. (2002). Forecasting Brazilian output in real time in the presence of breaks: A comparison of linear and non-linear models. Texto para Discussão 11, IPEA.

Chauvet, M. \& Piger., J. M. (2008). A comparison of the real-time performance of business cycle dating methods. Journal of Business and Economic Statistics, 26:42-49.

Contador, C. \& Ferraz, C. (1999). Previsão com Indicadores Antecedentes. Silcon, Rio de Janeiro.

Contador, C. \& Haddad, C. (1975). Produto real, moeda e preços: A experiência brasileira no período 1861-1970. Revista Brasileira de Estatística, Jul/Set:407-440.

Contador, R. C. (1977). Ciclos Econômicos e Indicadores de Atividade. INPES/IPEA, Rio de Janeiro.

Correa, A. S. (2003). Diferenças entre países da América Latina: Uma análise de Markov-Switching para os ciclos econômicos de Brasil e Argentina. Trabalho para Discussão 80, Banco Central do Brasil.

Duarte, A. J. M., Issler, J. V., \& Spacov, A. (2004). Coincident indices of economic activity and a chronology of Brazilian recessions. Pesquisa e Planejamento Econômico, 34(1):1-37.

Engle, R. \& Issler, J. (1993). Common trends and common cycles in Latin America. Revista Brasileira de Economia, 47(2):149-176.

Engle, R. F. \& Granger, C. (1987). Cointegration and error correction: Representation, estimation and testing. Econometrica, 55:271-276. 
Estrella, A. \& Mishkin, F. (1999). Predicting U.S. recessions: Financial variables as leading indicators. Review of Economics and Statistics, 80:45-61.

Forni, M., Hallin, M., Lippi, M., \& Reichlin, L. (2000). The generalized dynamic factor model: Identification and estimation. The Review of Economics and Statistics, 82(4):540-554.

Hamilton, J. D. (1989). A new approach to the economic analysis of nonstationary time-series and the business cycle. Econometrica, 57(2):357-384.

Harding, D. \& Pagan, A. (2002). Dissecting the cycle: A methodological investigation. Journal of Monetary Economics, 49(2):365-381.

Harvey, A. (1989). Forecasting, Structural Time Series and the Kalman Filter. Cambridge University Press, Cambridge.

Harvey, A. C. \& Pierse, R. G. (1984). Estimating missing observations in economic time series. Journal of the American Statistical Association, 79:125-131.

Hecq, A., Palm, F. C., \& Urbain, J.-P. (2006). Common cyclical features analysis in VAR models with cointegration. Journal of Econometrics, 132(1):117-141.

Hollauer, G., Issler, J., \& Notini, H. (2009). Novo indicador coincidente para a atividade industrial brasileira. Revista de Economia Aplicada, 13:5-28.

Issler, J. V. \& Notini, H. (2008). Estimating Brazilian monthly real GDP: A Kalman filter approach. Mimeo, FGV/EPGE.

Issler, J. V., Notini, H., \& Rodrigues, C. (2012). Constructing coincident and leading indices of economic activity for the Brazilian economy. Journal of Business Cycles Measurement and Analysis, 2012:2.

Issler, J. V. \& Spacov, A. D. (2000). Usando correlações canônicas para identificar indicadores antecedentes e coincidentes da atividade econômica no Brasil. Relatório de pesquisa, Mimeo.

Issler, J. V. \& Vahid, F. (2006). The missing link: Using the NBER recession indicator to construct coincident and leading indices of economic activity. Journal of Econometrics, 132(1):281-303.

Kwiatkowski, D., Phillips, P. C. B., Schmidt, P., \& Shin, Y. (1992). Testing the null hypothesis of stationarity against the alternative of a unit root: How sure are we that economic time series have a unit root? Journal of Econometrics, 54:159-178.

Kydland, F. \& Zarazaga, C. E. (1997). Is the business cycle of Argentina different? Federal Reserve Bank of Dallas, Fourth Quarter, pp. 21-36, Economic Review.

Lucas, R. E. (1977). Understanding business cycles. Carnegie-Rochester Conference Series on Public Policy, 5:7-29.

Marcelino, M. (2006). Leading indicators: What have we learned? Technical Report 4977, CEPR Discussion Papers.

Mariano, R. \& Murasawa, Y. (2003). A new coincident index of business cycles based on monthly and quarterly series. Journal of Applied Econometrics, 18:427-443.

Mönch, E. \& Uhlig, H. (2005). Towards a monthly business cycle chronology for the Euro area. Journal of Business Cycle Measurement and Analysis, 1(2):43-69.

Moore, G. \& Shiskin, J. (1967). Indicators of Business Expansions and Contrations. NBER. 
Neumeyer, P. \& Perri, F. (2005). Business cycles in emerging economies: The role of interest rates. Journal of Monetary Economics, 52(2):345-380.

Newey, W. \& West, K. (1987). A simple positive semi-definite, heteroskedascity and autocorrelation consistent covariance matrix. Econometrica, 55:703-708.

Phillips, P. \& Perron, P. (1988). Testing for a unit root in time series regression. Biometrika, 75:335-346.

Picchetti, P. \& Toledo, C. (2002). Estimating and interpreting a common stochastic component for the Brazilian industrial production index. Revista Brasileira de Economia, 56:107-120.

Spacov, A. (2000). Índices antecedentes e coincidentes de atividade econômica brasileira: Uma aplicação da análise de correlação canônica. FGV/EPGE, Dissertação de Mestrado.

Stock, J. \& Watson, M. (1988a). A new approach to leading economic indicators. Mimeo, Harvard University, Kennedy School of Government.

Stock, J. \& Watson, M. (1988b). A probability model of the coincident economic indicator. Technical Report 2772, NBER Working Paper.

Stock, J. \& Watson, M. (1989). New indexes of coincident and leading economic indicators. In NBER Macroeconomics Annual, pages 351-395. MIT Press.

Stock, J. \& Watson, M. (1993a). New research on business cycles, indicators and forecasting. In New Research on Business Cycles, Indicators and Forecasting. University of Chicago Press, for NBER.

Stock, J. \& Watson, M. (1993b). A procedure for predicting recessions with leading indicators: Econometric issues and recent experience. In Stock, J. H. \& Watson, M. W., editors, New research on business cycles, indicators and forecasting. University of Chicago Press, for NBER, Chicago.

Stock, J. \& Watson, M. W. (1991). A probability model of the coincident economic indicator. In Lahiri, K. \& Moore, G. H., editors, Leading Economic Indicators: New Approaches and Forecasting Records. Cambridge University Press, Cambridge.

Uribe, M. \& Yue, V. (2006). Country spreads and emerging countries: Who drive whom? Journal of International Economics, 60:6-36.

Vahid, F. \& Engle, R. F. (1993). Common trends and common cycles. Journal of Applied Econometrics, 8:341-360.

Vahid, F. \& Issler, J. V. (2002). The importance of common-cyclical features in VAR analysis: A Monte Carlo study. Journal of Econometrics, 109:341-363.

Zarnowitz, V. (1981). Business cycles and growth: Some reflections and measures. Technical Report 665, Working Papers.

Zarnowitz, V. (1985). Recent work on business cycles in historical perspective: Review of theories and evidence. Technical Report 1503, NBER Working Papers.

Zarnowitz, V. (1987). The regularity of business cycles. Technical Report 2381, NBER Working Papers. 


\section{A. APPEDINX TABLES}

Table A-1: Coincident Series - Description

\begin{tabular}{|c|c|c|c|c|}
\hline Country & Series Name & Description & Sample Period & Source \\
\hline \multirow{4}{*}{ Argentina } & Employment & Employment in the supermarket sector & 1997:01 - 2012:06 & MECON \\
\hline & Income & Nominal Wages index deflated by CPI & $2001: 10-2012: 06$ & INDEC \\
\hline & Industrial Production & Industrial Production Index & 1994:01 - 2012:06 & INDEC \\
\hline & Sales & Shopping Center Sales deflated by CPI & 1997:01 - 2012:06 & INDEC \\
\hline \multirow{4}{*}{ Brazil } & Employment & Total Employment in metropolitan areas & $2002: 03-2012: 06$ & IBGE \\
\hline & Income & Real Average wage index & $2002: 03-2012: 06$ & IBGE \\
\hline & Industrial Production & Industrial Production Index & 1980:01 - 2012:06 & IBGE \\
\hline & Sales & Production of Corrugated paper & 1980:01 - 2012:06 & IBGE \\
\hline \multirow{4}{*}{ Chile } & Employment & Total national employment & 1986:01 - 2012:06 & INE \\
\hline & Income & Real compensation per hour & 1993:04 - 2012:06 & INE \\
\hline & Industrial Production & Industrial Production Index & 1991:01 - 2012:06 & INE \\
\hline & Sales & Real Retail Sales & 1991:01 - 2012:06 & CNC \\
\hline \multirow{4}{*}{ Colombia } & Employment & Total national employment & 2001:01 - 2012:06 & DANE \\
\hline & Income & Real wages in manufacturing sector & 1990:01 - 2012:06 & DANE \\
\hline & Industrial Production & Industrial Production Index & 1980:01 - 2012:06 & DANE \\
\hline & Sales & Real Retail Sales excluding fuel & 1999:01 - 2012:06 & DANE \\
\hline \multirow{4}{*}{ Mexico } & Employment & Insured Workers & 1994:01 - 2012:06 & $\begin{array}{l}\text { Secretary of Labor } \\
\text { and Social Security }\end{array}$ \\
\hline & Income & Nominal Wages index deflated by CPI & 1980:01 - 2012:06 & INEGI \\
\hline & Industrial Production & Industrial Production Index & 1980:01 - 2012:06 & INEGI \\
\hline & Sales & Real Retail Sales & 1994:01 - 2012:06 & INEGI \\
\hline
\end{tabular}

Table A-2: Covariates - Description

\begin{tabular}{|c|c|c|c|}
\hline Country & Covariates & Sample Period & Source \\
\hline \multirow{2}{*}{ Argentina } & Cement Production & 1980:01 - 2012:06 & Association of Portland Cement \\
\hline & Monthly GDP & 1980:01 - 2012:06 & Estimated using Issler and Notini (2008) \\
\hline \multirow{4}{*}{ Brazil } & Corrugated Paper Production & 1980:01 - 2012:06 & ABPO \\
\hline & Energy Production & 1980:01 - 2012:06 & NOS \\
\hline & Cement Production & 1980:01 - 2012:06 & SNIC \\
\hline & Monthly GDP & 1980:01 - 2012:06 & Estimated using Issler and Notini (2008) \\
\hline \multirow{3}{*}{ Chile } & Manufacturing Employment & 1980:01 - 2006:03 & $\mathrm{IMF} / \mathrm{IFS}$ \\
\hline & Industrial Production & 1980:01 - 2011:12 & IMF/IFS \\
\hline & Monthly GDP & 1980:01 - 2012:06 & Estimated using Issler and Notini (2008) \\
\hline \multirow{4}{*}{ Colombia } & Industrial Production & 1980:01 - 2012:06 & DANE \\
\hline & Manufacturing Employment & 1980:01 - 2012:06 & DANE \\
\hline & Real Capital Goods Imports & 1980:01 - 2012:06 & DANE \\
\hline & Real Consumer Goods Imports & 1980:01 - 2012:06 & DANE \\
\hline \multirow{3}{*}{ Mexico } & Industrial Production & 1980:01 - 2012:06 & INEGI \\
\hline & Income & $1980: 01-2012: 06$ & INEGI \\
\hline & Monthly GDP & 1980:01 - 2012:06 & Estimated using Issler and Notini (2008) \\
\hline
\end{tabular}


Table A-3: Backcasted Series - Description

\begin{tabular}{|c|c|c|c|}
\hline Country & Backcasted Series & Covariates & Backcasting Period \\
\hline \multirow{4}{*}{ Argentina } & Employment & Monthly GDP and Cement Production & 1980:01 - 1996:12 \\
\hline & Income & Monthly GDP and Cement Production & 1980:01 - 2001:09 \\
\hline & Industrial Production & Monthly GDP and Cement Production & 1980:01 - 1993:12 \\
\hline & Sales & Monthly GDP and Cement Production & 1980:01 - 1996:12 \\
\hline \multirow{3}{*}{ Brazil } & Employment & Monthly GDP and Energy Production & 1980:01 - 2002:02 \\
\hline & Income & Corrugated Paper and Cement Production & 1980:01 - 2002:02 \\
\hline & Employment & Manufacturing Employment & 1980:01 - 1985:12 \\
\hline \multirow{3}{*}{ Chile } & Income & $\begin{array}{l}\text { Industrial Production, Manufacturing } \\
\text { Employment and Monthly GDP }\end{array}$ & 1980:01 - 1993:03 \\
\hline & Industrial Production & Industrial Production & 1980:01 - 1990:12 \\
\hline & Sales & $\begin{array}{l}\text { Industrial Production and Manufacturing } \\
\text { Employment }\end{array}$ & 1980:01 - 1990:12 \\
\hline \multirow{4}{*}{ Colombia } & & Industrial Production, Manufacturing & \\
\hline & Employment & $\begin{array}{l}\text { Employment, Real Imports of Capital } \\
\text { and Consumer Goods }\end{array}$ & 1980:01 - 2000:12 \\
\hline & Income & $\begin{array}{l}\text { Manufacturing Employment and Real } \\
\text { Imports of Consumer Goods }\end{array}$ & 1980:01 - 1989:12 \\
\hline & Sales & $\begin{array}{l}\text { Industrial Production, Manufacturing } \\
\text { Employment, Real Imports of Capital } \\
\text { and Consumer Goods }\end{array}$ & 1980:01 - 1998:12 \\
\hline \multirow[t]{2}{*}{ Mexico } & Employment & $\begin{array}{l}\text { Industrial Production, Real Income and } \\
\text { Monthly GDP }\end{array}$ & 1980:01 - 1993:12 \\
\hline & Sales & $\begin{array}{l}\text { Industrial Production, Real Income and } \\
\text { Monthly GDP }\end{array}$ & 1980:01 - 1993:12 \\
\hline
\end{tabular}


Table A-4: Coincident Series - Unit Root Tests

\begin{tabular}{|c|c|c|c|c|c|c|}
\hline \multirow{2}{*}{ Country } & \multirow{2}{*}{ Series Name } & \multicolumn{2}{|c|}{$\mathrm{ADF}$} & \multirow{2}{*}{$\begin{array}{c}\text { Kwiatkowski et al } \\
\text { L M-statistic }\end{array}$} & \multicolumn{2}{|c|}{ Phillips and Perron } \\
\hline & & t-statistic & p-value & & t-statistic & p-value \\
\hline \multirow{4}{*}{ Argentina } & Employment & 0,157 & 0,970 & $2.12^{*}$ & 0,134 & 0,968 \\
\hline & Income & 0,052 & 0,962 & $2.09^{*}$ & 0,248 & 0,975 \\
\hline & Industrial Production & 2,112 & 1,000 & $1.82^{*}$ & 2,121 & 1,000 \\
\hline & Sales & 1,000 & 0,997 & $1.84^{*}$ & 1,492 & 0,999 \\
\hline \multirow{4}{*}{ Brazil } & Employment & 0,238 & 0,975 & $2.21^{*}$ & 0,301 & 0,978 \\
\hline & Income & $-1,061$ & 0,732 & $2.11^{*}$ & $-0,772$ & 0,825 \\
\hline & Industrial Production & $-0,188$ & 0,937 & $2.32 *$ & $-0,449$ & 0,898 \\
\hline & Sales & $-1,140$ & 0,701 & $2.34^{*}$ & $-0,521$ & 0,884 \\
\hline \multirow{4}{*}{ Chile } & Employment & $-0,821$ & 0,812 & $2.26^{*}$ & $-1,602$ & 0,481 \\
\hline & Income & $-0,379$ & 0,910 & $2.31^{*}$ & $-0,237$ & 0,931 \\
\hline & Industrial Production & 0,612 & 0,990 & $2.37^{*}$ & 0,460 & 0,985 \\
\hline & Sales & $-0,628$ & 0,861 & $2.31^{*}$ & $-0,747$ & 0,832 \\
\hline \multirow{4}{*}{ Colombia } & Employment & 0,984 & 0,997 & $2.15^{*}$ & 0,870 & 0,995 \\
\hline & Income & $-0,381$ & 0,909 & $2.09 *$ & $-0,414$ & 0,904 \\
\hline & Industrial Production & 0,271 & 0,977 & $2.28^{*}$ & 0,236 & 0,975 \\
\hline & Sales & 0,686 & 0,992 & $2.30^{*}$ & 0,551 & 0,988 \\
\hline \multirow{4}{*}{ Mexico } & Employment & 0,065 & 0,963 & $2.38^{*}$ & $-0,038$ & 0,954 \\
\hline & Income & $-0,398$ & 0,907 & $2.33^{*}$ & $-0,515$ & 0,885 \\
\hline & Industrial Production & $-1,301$ & 0,631 & $0.73^{*}$ & $-1,826$ & 0,368 \\
\hline & Sales & $-0,100$ & 0,947 & $2.24^{*}$ & $-0,110$ & 0,946 \\
\hline
\end{tabular}

Notes: (i) ADF and Phillips and Perron : series has a unit root; Kwiatkowski : series is stationary. (ii) the asterisk $\left({ }^{*}\right)$ indicates that we reject the null hypothesis at $5 \%$.

Table A-5: Quarterly Turning Points - Argentina

\begin{tabular}{cccccc}
\hline & Quarterly GDP & \multicolumn{3}{c}{ Quarterly Coincident Index } \\
\hline Peak Dates & Through Dates & $\begin{array}{c}\text { Duration } \\
\text { (quraters) }\end{array}$ & Peak Dates & Through Dates & $\begin{array}{c}\text { Duration } \\
\text { (quraters) }\end{array}$ \\
\hline 1980:3 & $1982: 2$ & 7 & $<$ NA $>$ & $1981: 2$ & NA \\
$1984: 2$ & $1985: 3$ & 5 & $1984: 2$ & $1985: 3$ & 5 \\
$1987: 3$ & $1990: 1$ & 10 & $1987: 3$ & $1990: 2$ & 11 \\
$1994: 4$ & $1995: 3$ & 3 & $1992: 2$ & $1992: 4$ & 2 \\
$1998: 2$ & $2000: 3$ & 9 & $1994: 4$ & $1995: 4$ & 4 \\
$2001: 1$ & $2002: 1$ & 4 & $1998: 3$ & $1999: 3$ & 4 \\
$2008: 3$ & $2009: 2$ & 3 & $2000: 1$ & $2002: 1$ & 8 \\
& & & $2008: 3$ & $2009: 1$ & 2 \\
\hline
\end{tabular}


Table A-6: Quarterly Turning Points - Brazil

\begin{tabular}{cccccc}
\hline & Quarterly GDP & \multicolumn{3}{c}{ Quarterly Coincident Index } \\
\hline Peak Dates & Through Dates & $\begin{array}{c}\text { Duration } \\
\text { (quraters) }\end{array}$ & Peak Dates & Through Dates & $\begin{array}{c}\text { Duration } \\
\text { (quraters) }\end{array}$ \\
\hline 1980:4 & $1981: 4$ & 4 & $1980: 4$ & $1981: 3$ & 3 \\
$1982: 3$ & $1983: 1$ & 2 & $1982: 3$ & $1983: 1$ & 2 \\
$1988: 1$ & $1988: 4$ & 3 & $1987: 1$ & $1987: 3$ & 2 \\
$1989: 3$ & $1990: 2$ & 3 & $1989: 4$ & $1990: 2$ & 2 \\
$1991: 3$ & $1992: 3$ & 4 & $1991: 3$ & $1992: 2$ & 3 \\
$1995: 1$ & $1995: 3$ & 2 & $1995: 1$ & $1995: 3$ & 2 \\
$1998: 2$ & $1998: 4$ & 2 & $1997: 3$ & $1999: 1$ & 6 \\
$2001: 1$ & $2001: 4$ & 3 & $2000: 4$ & $2001: 3$ & 3 \\
$2002: 4$ & $2003: 2$ & 2 & $2002: 3$ & $2003: 2$ & 3 \\
$2008: 3$ & $2009: 1$ & 2 & $2008: 3$ & $2009: 1$ & 2 \\
\hline
\end{tabular}

Table A-7: Quarterly Turning Points - Chile

\begin{tabular}{cccccc}
\hline & Quarterly GDP & \multicolumn{3}{c}{ Quarterly Coincident Index } \\
\hline Peak Dates & Through Dates & $\begin{array}{c}\text { Duration } \\
\text { (quraters) }\end{array}$ & Peak Dates & Through Dates & $\begin{array}{c}\text { Duration } \\
\text { (quraters) }\end{array}$ \\
\hline $1981: 3$ & $1982: 4$ & 5 & $1981: 3$ & $1983: 1$ & 6 \\
$1990: 1$ & $1990: 3$ & 2 & $1989: 4$ & $1990: 3$ & 3 \\
$1998: 2$ & $1999: 1$ & 3 & $1998: 3$ & $1999: 2$ & 3 \\
$2008: 2$ & $2009: 1$ & 3 & $2008: 1$ & $2008: 3$ & 2 \\
\hline
\end{tabular}


Table A-8: Quarterly Turning Points - Colombia

\begin{tabular}{cccccc}
\hline & Quarterly GDP & & \multicolumn{3}{c}{ Quarterly Coincident Index } \\
\hline \multirow{2}{*}{ Peak Dates } & Through Dates & $\begin{array}{c}\text { Duration } \\
\text { (quraters) }\end{array}$ & Peak Dates & Through Dates & $\begin{array}{c}\text { Duration } \\
\text { (quraters) }\end{array}$ \\
\hline \multirow{2}{*}{$1998: 2$} & 4 & $<$ NA $>$ & $1980: 3$ & NA \\
& & $1981: 1$ & $1982: 1$ & 4 \\
& & $1982: 3$ & $1983: 2$ & 3 \\
& & $1983: 4$ & $1985: 1$ & 5 \\
& & $1987: 4$ & $1988: 4$ & 4 \\
& & $1990: 1$ & $1991: 2$ & 5 \\
& & $1995: 4$ & $1996: 4$ & 4 \\
& & $1998: 1$ & $1999: 1$ & 4 \\
& & $2000: 4$ & $2001: 2$ & 2 \\
& & $2002: 2$ & $2002: 4$ & 2 \\
& & $2008: 1$ & $2008: 4$ & 3 \\
\hline
\end{tabular}

Note: Quarterly GDP data for Colombia is available only since 1994

Table A-9: Quarterly Turning Points - Mexico

\begin{tabular}{cccccc}
\hline & Quarterly GDP & \multicolumn{3}{c}{ Quarterly Coincident Index } \\
\hline Peak Dates & Through Dates & $\begin{array}{c}\text { Duration } \\
\text { (quraters) }\end{array}$ & Peak Dates & Through Dates & $\begin{array}{c}\text { Duration } \\
\text { (quraters) }\end{array}$ \\
\hline 1981:4 & $1983: 2$ & 6 & $1982: 2$ & $1983: 4$ & 6 \\
$1985: 3$ & $1986: 4$ & 5 & $1985: 1$ & $1986: 4$ & 7 \\
$1987: 4$ & $1988: 3$ & 3 & $1987: 4$ & $1988: 3$ & 3 \\
$1994: 4$ & $1995: 2$ & 2 & $1994: 4$ & $1995: 3$ & 3 \\
$2002: 2$ & $2003: 1$ & 3 & $2000: 3$ & $2002: 1$ & 6 \\
$2008: 2$ & $2009: 2$ & 4 & $2008: 1$ & $2009: 2$ & 5 \\
\hline
\end{tabular}

Table A-10: Average Economy-state forecast Error (QPS)

\begin{tabular}{lcc}
\hline \multicolumn{1}{c}{ Country } & Peaks & Throughs \\
\hline Argentina & $4.62 \%$ & $8.46 \%$ \\
Brazil & $7.69 \%$ & $7.69 \%$ \\
Chile & $4.62 \%$ & $4.62 \%$ \\
Colombia & $8.11 \%$ & $8.11 \%$ \\
Mexico & $6.15 \%$ & $4.62 \%$ \\
\hline
\end{tabular}


Table A-11: Bernanke, Gertler, and Watson measures of fit

\begin{tabular}{|c|c|c|c|}
\hline \multirow{2}{*}{ Country } & \multirow{2}{*}{ Backasted series } & \multicolumn{2}{|c|}{$R^{2}$} \\
\hline & & Level & Diff \\
\hline \multirow{4}{*}{ Argentina } & Employment & 0.2012 & 0.2128 \\
\hline & Income & 0.1448 & 0.1453 \\
\hline & Industrial Production & 0.4381 & 0.4402 \\
\hline & Sales & 0.2050 & 0.2060 \\
\hline \multirow{2}{*}{ Brazil } & Employment & 0.5968 & 0.5979 \\
\hline & Income & 0.6634 & 0.6651 \\
\hline \multirow{4}{*}{ Chile } & Employment & 0.8398 & 0.8454 \\
\hline & Income & 0.7070 & 0.7088 \\
\hline & Industrial Production & 0.7567 & 0.7589 \\
\hline & Sales & 0.4441 & 0.4475 \\
\hline \multirow{3}{*}{ Colombia } & Employment & 0.3949 & 0.3960 \\
\hline & Income & 0.4959 & 0.5020 \\
\hline & Sales & 0.6187 & 0.6204 \\
\hline \multirow{2}{*}{ Mexico } & Employment & 0.5071 & 0.5092 \\
\hline & Sales & 0.5814 & 0.5828 \\
\hline
\end{tabular}

